NBER WORKING PAPER SERIES

\title{
FIFTY MILLION VOTERS CAN'T BE WRONG: ECONOMIC SELF-INTEREST AND REDISTRIBUTIVE POLITICS
}

\author{
Jacob L. Vigdor \\ Working Paper 12371 \\ http://www.nber.org/papers/w12371 \\ NATIONAL BUREAU OF ECONOMIC RESEARCH \\ 1050 Massachusetts Avenue \\ Cambridge, MA 02138 \\ July 2006
}

I am grateful to Philip Cook, James T. Hamilton, Erzo F.P. Luttmer, and seminar participants at the University of California-Berkeley, Indiana University-Bloomington, and Indiana University-Purdue University Indianapolis for helpful comments on an earlier draft, and to Jason Blevins for exceptional research assistance. Remaining errors are the author's responsibility. The views expressed herein are those of the author(s) and do not necessarily reflect the views of the National Bureau of Economic Research.

(C2006 by Jacob L. Vigdor. All rights reserved. Short sections of text, not to exceed two paragraphs, may be quoted without explicit permission provided that full credit, including $₫$ notice, is given to the source. 
Fifty Million Voters Can't Be Wrong: Economic Self-Interest and Redistributive Politics Jacob L. Vigdor

NBER Working Paper No. 12371

July 2006

JEL No. D31, D72, H31

\begin{abstract}
Why do voters at the lower end of the socioeconomic spectrum support political candidates who generally disfavor redistributive policies? Existing explanations often presume that voters are explicitly acting in opposition to their economic self-interest, or that they hold persistently optimistic expectations regarding the probability of moving into the upper ranks of the income distribution. This paper provides an alternative economic explanation. When voters evaluate their well-being by making relative utility comparisons, support for redistribution depends not only on absolute income but on one's status relative to a reference group. When reference groups are defined geographically, support depends on exposure to higher-income neighbors. The predictions of the model are supported by empirical evidence drawn from county-level election returns in 1980 and 2000, and by individual-level polling data following the 2000 election.
\end{abstract}

Jacob L. Vigdor

Terry Sanford Institute of Public Policy

Duke University

Durham, NC 27708

and NBER

jacob.vigdor@duke.edu 
[T] hose segments of the working class that have been hardest hit by the big economic changes of recent years are the very ones that vote Republican in the greatest numbers.

- Thomas Frank, What's the Matter with Kansas?

If in polished countries the lowest of the people are rude and uncivil, it is not merely because they are poor and ignorant, but because... they are in daily contact with rich and enlightened men. The sight of their own hard lot and their weakness, which is daily contrasted with the happiness and power of some of their fellow creatures, excites in their hearts at the same time the sentiments of anger and of fear: the consciousness of their inferiority and their dependence irritates while it humiliates them...In those places where the rich and powerful are assembled together, the weak and the indigent feel themselves oppressed by their inferior condition.

- Alexis de Tocqueville, Democracy in America [emphasis added]

\section{Introduction}

In the most straightforward economic model of policy-making, voters below the mean level of income support efforts to redistribute income, and those above the mean do not (Meltzer and Richard, 1981). Moreover, increases in the variance of the income distribution should increase demand for redistribution (Alesina and Rodrik, 1994; Persson and Tabellini, 1994). With this model explicitly or implicitly in mind, a number of commentators have puzzled over the demonstrated tendency for below-average income American households to vote for national candidates representing the less redistributive party, even in an era of increasing inequality. ${ }^{1}$ Figure 1 displays basic trends associated with this puzzle: income inequality rose steadily in two periods during the twentieth century, in the 1920s and after 1980. The first period witnessed a remarkable increase in support for the Democratic part. While voter support for Democratic presidential candidates has been trending upward during the latter period, the increase is much less dramatic.

1Glaeser (2005) notes a similar puzzle apparent in cross-national data on income inequality and redistribution, which shows a negative relationship. 
The most commonly advanced explanations for the lack of a voter response to inequality maintain that Republican strategists have managed to make the electorate forget about their own economic self-interest, by focusing their attention on issues of "values" or other nonpecuniary matters. Economists have also explained American apathy toward redistribution as a product of expectations regarding upward mobility (Benabou and Ok 2001a; Alesina and La Ferrara 2001). This paper proposes an alternative explanation: that the failure of rational voter models to explain electoral outcomes reflects not voters' disregard for their own self-interest, but social scientists' failure to correctly model it.

A growing body of empirical evidence suggests that individuals' evaluation of their own well-being depends not only on their absolute level of consumption, but on their consumption relative to others (Frank, 1985; Tomes, 1986; Easterlin, 2001; McBride, 2001; see Frey and Stutzer, 2002 for a review of the economic literature on subjective valuation of well-being). Evidence also suggests that individuals often use geographically localized comparison groups as a means of gauging their relative standing (Ferrer-i-Carbonell, 2004; Luttmer, 2005; Stutzer, 2004). In a model incorporating this form of benchmarking, support for redistribution should covary positively with the degree of socioeconomic heterogeneity in a local area. To the extent that local income distributions inform voters' expectations regarding the likelihood that their own income will rise, this prediction directly opposes that of the upward-mobility-expectation hypothesis.

This paper develops a formal political economy model where agents vote for negative income tax-type proposals and utilize both absolute and relative measures of consumption to evaluate their well-being. The model generates predictions for the case where voters form 
reference groups geographically, or by comparing themselves to others of similar socioeconomic stature. The paper tests the empirical predictions of this model using county-level election data merged to county-level Census demographic and socioeconomic data for 1980 and 2000, as well as individual-level polling data. The potential for endogenous sorting of voters into communities with varying income profiles is addressed by isolating the transitory component of variation in the income distribution, which presumably drives demand for redistribution more than it influences sorting decisions.

Results conform with the predictions of the model. Voters, particularly those at the low end of the income distribution, are more likely to support Democratic candidates when they reside in heterogeneous communities. Moderate-income voters increase their support for redistributive candidates as their neighbors shift from low- to high-income. There is some evidence that high income voters tendency to vote altruistically increases with their exposure to the poor. Finally, there is some evidence that voters with an "economic reference group" consisting primarily of households with lower income than their own - those on the steeply downward-sloping portion of the income distribution - exhibit the least support for Democratic candidates.

Thus, while non-economic factors may hold great importance for some voters, the socioeconomic profile of many so-called "Red states" coincides well with the profile of communities expected to disfavor redistribution under the revised definition of economic selfinterest. These states are by and large homogeneous, with neither large centers of poverty nor wealthy enclaves. A large fraction of residents fall in that portion of the income distribution where the density of households just below them exceeds the density of households just above 
them. The potential utility gains from redistributive policy, particularly along the margins where current political debates focus, are small for this group. These findings carry implications both for the design of optimal redistributive policy and for the tailoring of political messages to the electorate.

Section 2 reviews current and historical evidence on voting and income inequality. Section 3 presents a model of voter support for redistribution when utility depends on relative consumption. Section 4 describes the empirical strategy and data. Section 5 presents results, and Section 6 concludes.

\section{Voting, Income Inequality, and Other Trends in America}

Figure 1 plots the share of all voters supporting the Democratic candidate in every presidential election between 1896 and 2004. ${ }^{2}$ Points in the time series are color-coded to signify whether the incumbent ran for re-election, and if so whether the incumbent was a Democrat. $^{3}$ Figure 1 also plots a basic indicator of income inequality, taken from Piketty and Saez (2003): the share of income earned by individuals above the $90^{\text {th }}$ percentile in the income distribution. There are several noteworthy patterns in the graph. First, majority support for the Democratic party is rare. Of the twenty-eight elections plotted, the Democratic candidate received a majority of votes cast six times. ${ }^{4}$

Four of the six instances where Democrats earned a majority of votes are associated with

2 Note that it is traditional in studies of voting patterns to restrict attention to one party's share of the two-party vote (e.g. Fair, 2002). This figure thus highlights the relative importance of third party candidates in certain elections, such as 1992 when Ross Perot garnered a substantial share of the vote.

3 Incumbents generally have a strong advantage over challengers in elections. For an exploration of this phenomenon, see Lee (2001).

4 By contrast, the Republican candidate received an absolute majority in fourteen of the twenty-eight elections. The Democratic candidate was victorious in six of the eight elections where neither party's candidate earned an absolute majority - the exceptions being 2000 and 2004. 
a single candidate, Franklin Roosevelt. Roosevelt's initial election in 1932 marked a tremendous reversal of fortune for the party, which had received less than one-third of the popular vote just eight years before. ${ }^{5}$ As the time series show, this reversal of fortune followed upon the heels of a noticeable increase in income inequality. Roosevelt's election is often attributed to the onset of the Great Depression, but note that income inequality remained at an elevated level through the Depression, declining only after the nation's entry into World War II.

Democratic candidates' success against Republican incumbents effectively reverted to pre-Roosevelt era between 1956 and 1984, a period marked by relatively low and stable degrees of income inequality. ${ }^{6}$ In the last two decades of the century, the share of income accruing to the top decile rose again, and the time trend suggests a slight upward trend in support for Democratic candidates, evident particularly when comparing elections with the same incumbency pattern. Compared to the Roosevelt groundswell, however, this upward trend appears rather anemic. The absence of a stronger move towards Democratic candidates in the face of growing inequality has drawn both academic and popular attention, and is the puzzle at the heart of this paper.

There are several more pieces to this puzzle. Figure 2 depicts a scatterplot relating county-level voter support for the Democrat candidate, $\mathrm{Al} \mathrm{Gore,} \mathrm{in} \mathrm{the} 2000$ election to median income in 1999, as reported in the 2000 Census. Traditional political economy models would suggest a negative relationship between these two variables: counties with more poor residents should display greater support for the candidate associated with stronger redistributive policies. Instead, the correlation is modestly positive, as indicated by the least-squares regression line. ${ }^{7}$

5 A third party candidate, Robert LaFollette, received one-sixth of the popular vote in 1924.

6 The exception to this pattern is Carter's election in 1976, which marked the first election after the Watergate scandal and the first election where the incumbent was elected neither to the presidency or the vice presidency. 7 The regression line in Figure 2 reflects an unweighted least-squares specification. Weighting observations by 2000 population, or by the number of votes cast in the 2000 election, produces very similar results. 
Another widely noted political phenomenon of the past half-century is the transformation of the deep South from a solidly Democratic to solidly Republican region. Democratic candidate Adlai Stevenson received electoral votes from nine states in 1952; John Kerry won twenty states in 2004. The set of states won by both candidates in their respective elections is empty. Traditional explanations for the conversion of the South focus on the Democratic party's association with the Civil Rights movement, or with Republican attempts to court socially conservative voters with essentially non-economic policy positions.

A commonly stated hypothesis for the relatively weak support for redistributive policy in the United States focuses on voters' perceptions of the prospects for upward mobility (Alesina and La Ferrara, 2001; Benabou and Ok, 2001a; Benabou and Tirole 2005). The weak voter response to income inequality since 1980 might then be explained by a contemporaneous increase in income mobility, or a change in voter perceptions of the potential future benefits of inequality. Available evidence is not supportive of either trend. Benabou and Ok (2001b), studying income mobility in the PSID, find little evidence of a structural change in mobility patterns between the 1980s and 1990s. Evidence on attitudes towards inequality, collected by the General Social Survey and summarized in Figure 3, show that Americans generally adopted less favorable attitudes towards income inequality between the mid-1980s and mid-1990s. The proportion of respondents answering "disagree" or "strongly disagree" to the statement "large differences in income are necessary for America's prosperity" increased from $37 \%$ in the earlier period to $58 \%$ in the later period. ${ }^{8}$ Evidence presented below also argues against the upwardmobility-expectation hypothesis, unless voter expectations of mobility covary negatively with 8 A similar shift in opinions can be seen in responses to the query "It is the responsibility of the government to reduce the differences in income between people with high incomes and those with low incomes." In the mid1980 s, half of all respondents either disagreed or strongly disagreed with this statement. In the 1996 survey, this proportion declined to $43 \%$. 
heterogeneity in the local income distribution.

Finally, the increase in income inequality in the later part of the century was accompanied, at least through 1990, by an increase in the economic segregation of the nation's cities and metropolitan areas (Jargowsky, 1995). While measurement problems render it difficult to identify the trend in economic segregation prior to 1970 , the principal demographic trend associated with this increase - suburbanization - can be traced back to much earlier points in time (Jackson, 1985). The tendency for voters to reside in increasingly homogeneous communities thus may have reduced the particular effect of inequality noted by Tocqueville in the passage quoted above, by leading them into less frequent contact with "rich and enlightened men."

The interconnections between these various trends and observations are made in the following section.

\section{Who Supports Redistribution if Relative Consumption Matters?}

Previous research in public economic theory has established that when consumer welfare depends at least to some extent on relative rather than absolute consumption, optimal tax and transfer policies are more redistributive (Boskin and Sheshinski, 1978), optimal levels of public good expenditures exceed the standard Samuelsonian level (Ng, 1987), and optimal fiscal policies should be more countercyclical (Ljungqvist and Uhlig, 2000). Comparatively less attention has been paid to the topic of voter behavior in this scenario. This section uses a basic negative income tax model to analyze the effect of relative income comparsion on voters' support for redistribution. With this conceptual framework, it is possible to link together and explain 
many of the phenomena reported in the preceding section.

As in Boskin and Sheshinski (1978), suppose that voters derive earn income $y$ as a function of their own (exogenous) ability $n$ and an educational input $x$. The cost of acquiring $x$ is an increasing and concave function $g(x)$. For simplicity, assume that $y(n, x)=n x$ and $g(x)=x^{2}$. Voters are responsible for choosing a negative income tax policy that produces net-of-transferand-educational-investment income $y^{\prime}$ :

(1) $y^{\prime}=\alpha+\beta y-g(x)$,

which, substituting for $y$ and $g(x)$, can be expressed as

(2) $y^{\prime}=\alpha+\beta n x-x^{2}$.

In a model where only absolute consumption enters the utility function, the median voter will select values of $\alpha, \beta$, and $x$ that maximize her net-of-transfer-and-education-investment income subject to the balanced-budget constraint:

$$
I \alpha=\beta \sum_{i} n_{i} x_{i}
$$

where $i$ indexes the $I$ individuals in the economy, and each individual $x_{i}$ is presumed to be chosen optimally given $\beta$. In this framework, it is relatively straightforward to solve for the optimal educational investment $x$. The first order condition is:

(4) $\beta n-2 x=0$,

which yields an optimal value for $x$ as $\frac{\beta n}{2}$. Substituting this solution into the balancedbudget constraint (3) and the objective function (2), and then solving (3) for $\alpha$ and substituting into (2), yields an unconstrained maximization problem in a single variable, $\beta$ :

(5) $\frac{1}{2 \mathrm{I}} \sum_{i}\left(\beta-\beta^{2}\right) n_{i}^{2}+\frac{1}{4} \beta^{2} n^{2}$. 
First-order conditions provide the following solution for a voter's optimal choice of $\beta$ :

$$
\hat{\beta}=\frac{\frac{\sum_{i} n_{i}^{2}}{2 \mathrm{I}}}{\frac{\sum_{i} n_{i}^{2}}{I}-\frac{n^{2}}{2}} \cdot
$$

Table 1 presents some simple results using this formulation. In a three-voter economy with ability levels $\{0,0,1\}$, the median voter sets $\beta=1 / 2$. In an economy with ability levels $\{0,1,1\}$, second order conditions for a maximum do not hold, so the median voter selects the corner solution $\beta=1$. These results are quite intuitive: when the median voter is below the mean income, tax rates are set at a relatively high level, and when the median voter is above the mean income, tax rates are set to zero. The third row of Table 1 presents the case where ability levels are $\{0,1,2\}$. In this case, the median voter selects an intermediate value for $\beta$ of $5 / 7 .{ }^{10}$

As a straightforward way of introducing relative consumption into the model, suppose that utility is a simple linear function of own consumption and that of a reference person. Consumption of the reference person enters negatively, with a weight $0 \leq \gamma \leq 1$. When $\gamma=0$, relative consumption is not a concern. When $\gamma=1$, the impact of the reference person's consumption on utility is equal and opposite to the effect of own consumption. ${ }^{11}$ Denoting a voter's own ability as $n_{j}$ and the reference person's as $n_{k}$, the single-variable objective function (5) can be rewritten as:

9 Note that second-order conditions require that the denominator be positive for this solution to maximize the objective function. An example of a situation where second-order conditions do not hold, and the solution in that case, are discussed below.

10 In this case, note that the median voter ends up with a pre-transfer income below the mean, in spite of the fact that her ability level equals the mean.

11 While this latter scenario may seem extreme, it is consistent with the empirical results recorded by Luttmer (2005). 
(7) $\frac{1-\gamma}{2 \mathrm{I}} \sum_{i}\left(\beta-\beta^{2}\right) n_{i}^{2}+\frac{1}{4} \beta^{2} n_{j}^{2}-\frac{\gamma}{4} \beta^{2} n_{k}^{2}$,

and first-order conditions yield the following expression for the optimal $\beta$ :

(8) $\hat{\beta}^{R}=\frac{1-\gamma \frac{\sum_{i} n_{i}^{2}}{2 \mathrm{I}}}{\frac{1-\gamma \sum_{i} n_{i}^{2}}{I}-\frac{n_{j}^{2}}{2}+\frac{\gamma n_{k}^{2}}{2}}$.

As expected, when $\gamma=0$ this reduces to (6). When $\gamma=1$, second-order conditions for a maximum do not hold, leading to consequences described in more detail below. At intermediate levels of $\gamma$, this altered formula yields the tax rate most preferred by each voter.

The remaining rows of Table 1 illustrate how a voter's preferred level of $\beta$ varies with her own ability level, the reference person's ability level, and the extent to which relative rather than absolute consumption matters for utility. In a three-voter economy with voter ability levels $\{0,0,1\}$, the median voter's choice of $\beta$ now depends on the value of $\gamma$ and the identity of the reference person. If the median voter refers to the other voter with ability level 0 , the original preferred net-of-tax rate $\beta=1 / 2$ is chosen at the minimum and any intermediate level of $\gamma$. When $\gamma=1$, second order conditions fail to hold, and the voter becomes exactly indifferent between any and all values of $\beta$.

When the reference person is the individual with ability level 1 , the median voter continues to choose $\beta=1 / 2$ when relative comparisons do not matter, but reduces the value increasing the implied marginal tax rate - as interpersonal comparisons increase in importance. At $\gamma=1 / 2$, the preferred $\beta=1 / 5$, and at $\gamma=1$, the preferred $\beta=0$. Intuitively, when the median voter compares herself to the higher-ability consumer, an additional benefit from selecting high 
tax rates comes into play, as the reduction in the income of the high-ability consumer raises utility directly.

Finally, note that the high-ability consumer always prefers the zero-redistribution $\beta=1$, since the addition of interpersonal comparisons only increases the incentive to avoid transferring income to others.

In the three-voter economy with ability levels $\{0,1,2\}$ and $\gamma=1 / 2$, the median voter chooses $\beta=5 / 16$ when the reference person is the high-ability consumer. Note that this net-of-tax rate is considerably smaller than in the model where only absolute consumption matters. ${ }^{12}$ When the reference person is the low-ability consumer, the median voter chooses the no-redistribution outcome $\beta=1$. Even though the median voter's absolute consumption level stands to increase with a redistribution scheme, the greater benefits enjoyed by the low-ability consumer lead to a reduction in overall utility.

Overall, the model yields the following insights:

- Low-ability voters who care about relative consumption will favor stronger redistribution as the ability level of their reference group increases.

- Moderate-ability voters who care about relative consumption will favor stronger redistribution when their reference group is of higher ability, and weaker redistribution when their reference group is of lower ability.

- As interpersonal comparisons become more important to utility, the relative position of the voter and the reference group become more critical determinants of preferences for redistribution. In the extreme, when $\gamma=1$, voters with ability levels above the reference group favor state confiscation of all resources, voters with ability levels below the

12 Were the median voter to compare herself with another individual with $n=1$, the preferred $\beta$ would be $5 / 7$, 
reference group favor zero redistribution, and voters with ability levels exactly equal to their reference group are exactly indifferent between any policy alternatives.

\section{Introducing altruism}

While the model above posits that support for redistribution is driven primarily by self interest, there is also ample evidence that voters behave altruistically toward the poor, albeit often in a selective manner (Luttmer 2001). Altruistic behavior can be introduced straightforwardly into the model above, by allowing the weight on others' consumption in the utility function, $\gamma$, to be negative, and setting the reference person to be the poorest in the group. ${ }^{13}$ It is straightforward to show that when $\gamma$ is sufficiently negative, voters select tax rates higher than they would in the absence of interpersonal comparisons. Moreover, median voters acting on altruistic preferences select higher tax rates as the reference person's ability declines. ${ }^{14}$

\section{A note on rank-order models}

When voters care about their rank in the income distribution, as in Layard (1980), the introduction of relative consumption concerns into a negative income tax framework is inherently uninteresting, as such a policy cannot influence rank orderings. Voters will continue to base their support for redistribution on its effects on their absolute level of consumption.

Two reasonable extensions of the above model could allow for rank-order concerns to influence support for redistribution. First, the introduction of redistributive programs with discrete eligibility cutoffs introduce the possibility of reversing some rankings in the income

13 This extension need not imply that high-income voters act purely out of altruistic care for the poor. Appeasement in the classic Marxist sense could lead to very similar behavior.

14 As an example, consider communities with composition $\{0,2,2\}$ and $\{1,2,2\}$ when $\gamma=-3$. In the former case, the median voter selects $\beta=15 / 19$, and in the latter case $\beta=33 / 35$. 
distribution, or at the very least compressing the rankings. ${ }^{15}$ This sort of program would receive relatively low support from those who expect to fall just above the eligibility threshold.

Second, suppose income in future periods is uncertain and follows a random walk, with period-to-period innovations based on mean-zero independently distributed shocks, and that voters are at least somewhat risk averse. If a voter's net transfer payment in period $t$ is realized before the shock to income in that period, then a negative income tax may increase the likelihood of a rank reduction. ${ }^{16}$

\section{Defining a reference group}

If voters determine their support for redistributive policy in part by gauging the impact it would have on themselves relative to a reference group, the selection of reference groups by individual voters plays a critical role in determining the total amount of redistribution in the economy. As noted above, recent empirical evidence is consistent with the notion that geography plays a strong role in reference groups (Ferrer-i-Carbonell, 2004; Luttmer, 2005; Stutzer, 2004). When reference groups are geographic in nature, the model presented here suggests that support for redistribution among the poor should be highest when the poor share neighborhoods or regions with the wealthy. If the wealthy exhibit altruism of the sort discussed above, then their support for redistribution should likewise increase with their exposure to the poor. Poor or altruistic wealthy voters who live in homogeneous communities should exhibit the least support for redistribution conditional on income. Middle-income voters should support

15 It is not uncommon for transfer programs to involve these types of discrete changes in benefits. For a discussion of the economic implications, see Yelowitz (1995).

16 While this particular ordering of events may seem unintuitive, it could be compared to the awarding of tax refunds for year $t$ - 1 roughly one-third of the way through year $t$, or to the awarding of ex post tax rebates such as those enacted twice in the United States since 2001 (Shapiro and Slemrod, 2003). 
redistribution when they share communities with the wealthy, but oppose it when they reside in close proximity to the poor (unless they too exhibit altruism). These implications of the use of geographic reference groups, coupled with the tendency toward greater economic segregation noted in section 2 above, provides one possible explanation for the failure of increasing inequality to inspire stronger support for redistribution among low-to-moderate income voters.

Voters may use factors other than geographic proximity to form reference groups. One possibility is that voters evaluate their well-being by comparing themselves to those of comparable socioeconomic status, defined by occupation, education level, or income itself. In such a case, the key to support for redistribution may lie in the shape of the probability density function of the income distribution. Suppose individuals' reference groups consist of those households with income within a finite range of their own. On the upward sloping portion of the income distribution, mean income within reference groups tends to be higher than the voter's own income. On the downward sloping portion, the opposite is true. On relatively flat portions, reference group means tend to be close to the voter's own income.

Figure 4 summarizes these predictions, utilizing an income distribution graph that bears much resemblance to the actual distribution in the United States in recent decades. Perhaps the most noteworthy prediction here is that opposition to redistribution will actually be stronger amongst those on the steeply downward sloping portion of the income distribution than among those in the comparatively flat upper tail.

How does this framework link the economic and political trends observed during the twentieth century? First, the sorting of Americans into more economically homogeneous communities over time should have the effect of blunting the impact of income inequality on 
support for redistribution. To the extent that counties with higher median incomes have greater income heterogeneity, a cross-sectional relationship such as that plotted in Figure 2 is to be expected.

Second, changes in the shape of the American income distribution have placed a higher fraction of the population in a situation where there exists a greater mass of households immediately below them relative to above them. Figure 5 displays kernel density plots of the family income distribution in the United States, based on decennial Census data, for 1940, 1960, 1980 and $2000 .{ }^{17}$ Relative to the plots in the first three years, the income distribution in 2000 features a much higher peak and considerably less mass in the upper tail. The majority of voters now find themselves on a relatively steep downward-sloping portion of the income distribution, in marked contrast to earlier decades.

Finally, this framework can provide an explanation for the transference of Southern political allegiance from the Democratic to Republican side with one additional assumption. In the era of legal segregation, the reference groups of relatively poor white voters may have consisted only of other whites. Along with ending most forms of legally enforceable racial segregation, Civil Rights-era legislation may have changed the perceptions of these poor white voters, leading them to consider African-Americans as part of their reference group. The model presented in this section clearly predicts that the emergence of a new low-income reference group should reduce support for redistribution among those of moderate income, so long as those moderate income voters do not harbor altruistic sentiments toward the low-income group.

17 The kernel densities omit families in the top $1 \%$ of the income distribution, which are often topcoded, and those with negative or zero income. Densities have been rescaled to provide common support - the plots for years earlier than 2000 should not be construed to represent income in 2000 dollars. 


\section{Data and Methods}

The model outlined above promotes several testable implications. To the extent that voters use relative consumption comparisons to judge their own well-being, and compare themselves to those in close geographic proximity, then low-income voters will show greater support in heterogeneous rather than homogeneous communities. Moderate-income voters will show greater support when they share communities with wealthier neighbors, unless they are highly altruistic. High-income voters, to the extent they are altruistic, will show greater support in heterogeneous communities. To the extent that voters compare themselves to households of similar socioeconomic status, rather than those in close proximity, support for redistribution should follow the pattern outlined in Figure 4.

The empirical tests reported in this paper make use of two data sources. The first is voting data geographically aggregated to the county level, matched with county-level demographic data derived from the US Census. Analyses using aggregated data are performed using the last two presidential elections that coincided with Census enumerations, 1980 and 2000. The second data source is derived from two post-election polls conducted jointly by CBS News and the New York Times in late November and mid-December 2000. Individual poll responses, including the candidate voted for in the 2000 election, income, and other items, are merged with county-level statistics on income and other indicators.

When using individual-level data, the theoretical model described in the preceding section can be operationalized as follows:

$$
\operatorname{Pr}\left(Y_{i j k}=1\right)=\alpha_{j}+\beta X_{i j k}+\gamma Z_{k}+\sum_{m=2}^{J} \delta_{j m} s_{m k},
$$

where the outcome variable $Y_{i j k}$ represents support for a Democrat, $X_{i j k}$ is a vector characteristics 
for individual $i$ belonging to group $j$ in community $k, Z_{k}$ is a vector of community characteristics, and $s_{m k}$ represents the share of individuals in community $k$ who belong to group $m$. The intercept parameter $\alpha_{j}$ may take on different values for members of different groups. The parameter $\delta_{j m}$ measures the change in voting patterns associated with a shift in the composition of the population away from the omitted group category and into group $m \in[2, J]$. Specifications presented below will frequently impose constraints on the $J(J-1)$ different parameters $\delta_{j m}$.

Following the logic of Vigdor (2002) and Vigdor (2004), equation (9) when aggregated across individuals produces the following equation for the average probability of support for a Democratic candidate in community k:

$$
\operatorname{Pr}\left(Y_{k}=1\right)=\sum_{j=1}^{J} \alpha_{j} s_{j k}+\beta \bar{X}_{i j k}+\gamma Z_{k}+\sum_{j=1}^{J} \sum_{m=2}^{J} \delta_{j m} s_{m k} s_{j k}
$$

Equation (10) makes clear that it is impossible to identify the full set of coefficients $\delta_{j m}$ without imposing further parameter restrictions, as $s_{m k} s_{j k}=s_{j k} s_{m k}$. An additional set of parameter restrictions is required to avoid collinearity, since the $s_{j k}$ sum to one. One relatively straightforward restriction is to presume that voters are influenced primarily by the share of their own group in the population. With this restriction, equation (10) can be rewritten as the following:

$$
\operatorname{Pr}\left(Y_{k}=1\right)=\sum_{j=1}^{J} \alpha_{j} s_{j k}+\beta \bar{X}_{i j k}+\gamma Z_{k}+\sum_{j=1}^{J} \delta_{j} s_{j k}^{2}
$$

With the additional assumption that the parameters $\delta_{j}$ are equal across groups, assuming a common value $\delta$, the equation takes the form

$$
\operatorname{Pr}\left(Y_{k}=1\right)=\sum_{j=1}^{J} \alpha_{j} s_{j k}+\beta \overline{X_{i j k}}+\gamma Z_{k}+\delta \sum_{j=1}^{J} s_{j k}^{2}
$$


In this equation, the parameter $\delta$ is the coefficient on a Herfindahl-like index of income homogeneity. In completely homogeneous communities, this variable takes on the value of one. As communities become more heterogeneous, this variable takes on values closer to zero.

The assumptions associated with moving from equation (10) to equation (12), though straightforward, are not necessarily well aligned with theoretical predictions. Theory suggests, for example, that moderate-income voters will respond differently to increases in the low-income and high-income shares of the population. Equations (11) and (12) do not permit such a heterogeneous response. It is also quite possible that low income voters' response to increased income heterogeneity, rooted in decreased utility from interpersonal comparisons, is not of the same magnitude as high income voters' response, which would be rooted in altruism. Equation (11) allows these differential responses, while equation (12) does not. Empirical specifications reported below will offer some versions of each of the above equations, with constraints motivated by the theoretical discussion above applied to equation (10).

Aggregated regressions, as well as some individual-level regressions, control for a number of community characteristics. Controls for racial composition will capture the established tendency for minority voters to support Democratic candidates. The racial group shares will also be combined into a racial homogeneity index. Under assumptions analogous to those described above, the coefficient on this index describes the typical voter's response to a decrease in her group's share of the population.

Several covariates aim to capture the character of the community. Controls for the percent of the population residing in urban areas proxy for the community's density, while possibly addressing specific policy concerns in rural areas such as access to government-owned 
land. Controls for the percent of housing units built within the past decade, home ownership rates, and the fraction of households who have lived in the same house for at least five years, will capture the relative stability of the local population. Finally, specifications control for the percent of residents who work as government employees, and as active-duty members of the armed forces. Summary statistics for county-level regression covariates appear in Table 2.

Individual-level regressions, in addition to controlling for some community-level average characteristics, utilize covariates derived from the CBS/New York Times poll data. These variables include categorical controls for educational attainment, race, marital status, whether children are present in the respondent's household, and gender. The basic hypotheses outlined above are tested with intervalled data by matching respondent's (intervalled) income reports to Census data on the share of households with similar, higher, and lower incomes in the same county. Summary statistics for these individual-level variables appear in Table 3.

The potential for non-random sorting of individuals into communities of varying heterogeneity is a serious concern for this analysis. Rather than reflect the impact of communitylevel variables on voting patterns, the estimates might merely reveal the tendency for individuals who care for those in different income brackets to also choose locations in proximity to such individuals. $^{18}$

The strategy employed below to address this concern rests on two assumptions. First, to the extent that households choose communities on the basis of income heterogeneity, they are more concerned with permanent rather than transitory variation. Second, households' attitudes towards redistribution are driven by both permanent and transitory variation in their

18 Basic evidence that this is not the case can be derived from Rhode and Strumpf's (2003) finding that withincommunity heterogeneity has increased steadily over the past century or more. If such a movement reflected stronger preferences for redistribution, one would expect it to be accompanied by increasing vote shares for political parties favoring redistribution. As Figure 1 shows, this is clearly not the case. 
community's income distribution. ${ }^{19}$ Under these assumptions, selection effects will be associated primarily with permanent variation in income heterogeneity, while treatment effects will associate with both permanent and transitory variation. In some specifications, then, I will employ a measure of "transitory" income heterogeneity: that portion of income heterogeneity within a county that is orthogonal to lagged measures of the same variable.

\section{Results}

Table 4 presents baseline regression results employing 2000 county-level voting data merged to socioeconomic and demographic data from the 2000 Census. The first specification reported is a basic bivariate model, revealing the strength of the unconditional linear relationship between the income homogeneity index and Al Gore's share of the two-party presidential vote. ${ }^{20}$ The relationship is negative and statistically significant, explaining about $1 \%$ of the underlying variation in Gore's share. The magnitude of the coefficient suggests that a one-standard deviation increase in homogeneity predicts a 1.5 percentage point, or one-tenth standard deviation, drop in support for the Democratic candidate. Applying the behavioral interpretation discussed above, a percentage point increase in an individual's own income group share is associated with a 1.9 percentage point decline in the probability of supporting Gore.

Referring to equation (12), the first estimated regression imposes the assumption that all income categories have the same baseline propensity to vote for Gore (same value of $\alpha$ ). Controlling for group shares, as in the second specification, relaxes this assumption. The magnitude of the estimated coefficient on the homogeneity index increases substantially in this

19 Empirical evidence suggests that individuals do respond positively to transitory income shocks suffered by members of their community. See, for example, Hungerman (forthcoming).

20 In contrast to Figure 1, which used national-level data on the Democrat's share of all votes, these specifications show Gore's share of the two-party vote, primarily because of cross-state variation in the number of third-party candidates on the ballot. 
specification. A standard deviation increase in homogeneity now predicts a 5 percentage point drop in support for Gore.

The third specification incorporates the county-level covariates described in the preceding section. Here, the estimated impact of income homogeneity largely reverts to its initial level. A number of included covariates show significant relationships with voting patterns. Almost universally, higher nonwhite shares predict greater support for the Democratic party. Racial heterogeneity, by contrast, predicts less support. This pattern can be given an interpretation analogous to that motivated by equation (12) above: nonwhite groups show evidence of a greater propensity to support redistribution, but all groups' support increases when their share of the population increases. This pattern is consistent with Luttmer's (2001) finding that support for welfare spending increases when local welfare recipients are drawn disproportionately from one's own racial category.

Communities that are more highly urbanized, slower-growing, with fewer homeowners and fewer single-family detached housing units are more likely to support the Democratic party. One possible explanation for this finding is that older, denser urban communities are more likely to bring the rich and poor in close contact with one another. This possibility will be evaluated below.

Controlling for income, race, and community characteristics, there are few significant associations between a county's employment distribution and voting patterns. The principal exception to this concerns individuals on active duty military: counties with a significant military presence are more likely to vote Republican.

In addition to predictions regarding the impact of county-level income homogeneity, the 
model outlined in section 3 suggested a potentially nonlinear relationship between household income and support for redistribution. This prediction could be tested using the coefficients on the various income category variables included in the second and third regressions in Table 2 . In practice, the coefficients on these fifteen variables are imprecisely estimated, perhaps because they are jointly highly correlated. Rather than report these coefficients, the fourth regression in Table 2 collapses income categories into three. The first category, those with incomes below $\$ 25,000$ per year in 1999 , corresponds to the group on the upward-sloping portion of the 1999 income distribution, as evident in Figure 5, which is drawn from Census microdata. The second category, those with incomes below $\$ 25,000$ and $\$ 75,000$, identifies households on the steeply sloped portion of the income distribution. Those with incomes above $\$ 75,000$ are considered to be in the tail of the distribution, and form the omitted category in Table 4.

The fourth regression indeed shows a nonlinear relationship between income and support for redistribution. Adopting the behavioral interpretation outlined in the preceding section, it implies that the highest income group has the greatest propensity to vote for Democrats, followed by the lowest group. The group on the steep portion of the income distribution, as predicted, shows the greatest evidence of opposition to redistribution. Collapsing the fifteen income categories into three has only a modest impact on the model's fit, as indicated by the Rsquared statistic. This specification change also has the impact of reducing the estimated relationship between income homogeneity and support for Al Gore. A one-standard deviation increase in homogeneity now predicts a 0.8 percentage point decline in support. In this specification, civilian government employees appear as a significant positive predictor of support for the Democratic party. 
The final specification in Table 4 introduces state fixed effects, which force the remainder of the coefficients in the model to be identified on the basis of within-state variation. While allowing state-specific intercepts appreciably improves the model's fit, impact on most estimated coefficients is relatively unremarkable. This model does, however, estimate a relationship between income and support for Al Gore more consistent with the prediction offered above: low-income voters now show the highest propensity to support the Democratic candidate, followed by high-income voters. Including state fixed effects leads to a slight strengthening of the estimated relationship between income homogeneity and opposition to the Democratic party.

The impact of income homogeneity on voting need not be uniform across all communities or among all types of voters. In sparsely populated areas, heterogeneity in the income distribution may be insufficient to guarantee frequent contact between individuals from different points in the socioeconomic spectrum, implying that county-level measures of heterogeneity poorly reflect the composition of an individual's reference group. Moreover, the model above indicates that moderate income voters will react differently to increases in the share of high and low income voters, and more generally that the reaction to heterogeneity can differ among voters with different incomes. Table 5 offers evidence on these hypothesized sources of heterogeneity in the effect of homogeneity.

The first specification in Table 5 shows that the effect of income homogeneity is essentially zero in completely rural counties. The link between the income distribution and voting patterns is strongest in urban areas, consistent with the notion that rural environments are not conducive to the creation of geographically-based reference groups, at least when counties serve as the relevant geographic unit. 
The second regression estimates a version of equation (11) above, rather than equation (12). Following the interpretation outlined above, the individual controls for squared group share terms allows the impact of a percentage point increase in group share on that group's propensity to support Al Gore to vary across groups. The controls on the linear group share terms reveal groups' baseline propensity to support that candidate. Consistent with predictions and earlier results, the middle-income group representing the steeply downward sloping portion of the income distribution continues to display the least support for the redistributive party. The sensitivity of voter support to group share varies considerably across groups. Evidence suggests that both low-income and high-income voters become less likely to support redistribution as their share of the county population increases. The opposite pattern emerges for the middle income group - as their share of the population increases, they become more likely to support redistribution. This would be expected if the primary source of variation in the middle group's share is changes in the proportion in the low income group.

The final specification in Table 5 estimates a version of equation (10), imposing several parameter constraints: adopting the behavioral interpretation of coefficients, these constraints imply that low-income voters do not distinguish between middle and high income groups, and that high income voters do not vary their behavior with the income composition of their local area. This last constraint effectively rules out altruism as a motivation for the voting patterns of the wealthy. Relative to the prior specification, then, the constraint that has been relaxed is the one restricting moderate income voters to respond equally to increases in the high and low income shares of the population. This constraint is clearly inconsistent with the model presented in Section 3, and results clearly show a significant difference. In the place of the squared middle 
income group share, the specification introduces interactions between middle and low group shares, and between middle and high group shares.

Under the various assumptions underlying a behavioral interpretation of these results, moderate income voters are significantly less likely to support the redistributive party as the share of low income voters increases in their county. Shifts between the moderate and high income categories have no significant impact on the voting behavior of the middle income group. Note also that evidence suggests that low income voters continue to support redistributive candidates most fervently when they form a small share of the population.

To this point, analysis has treated the degree of income homogeneity in a county as an exogenous feature to which voters respond. This is obviously not the most accurate conceptualization of the variable. Rather, income homogeneity is determined in part by a process of household spatial sorting, which may lead individuals with greater distaste for members of other groups to both sort into homogeneous areas and vote against candidates associated with policies that imply the sharing of resources across groups. In this scenario, exogenously changing the degree of heterogeneity in any one area would not necessarily lead to any change in voting behavior.

Some of the variation in income homogeneity across counties is driven by transient, idiosyncratic factors: manufacturing plant shutdowns, corporate restructurings and the like. Under the presumption that household sorting processes are unlikely to respond to these transient sources of variation, estimates based on this source of variation have the potential to circumvent any bias associated with endogenous sorting processes. To implement this strategy, income homogeneity data for 1980 and 2000 were merged into a single dataset, and the following 
regression equation was estimated:

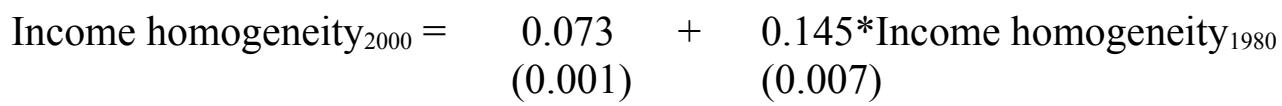

The regression equation has 3,116 observations; the raw correlation between the two variables is 0.34. Residuals from this regression are then employed as measures of the degree of income homogeneity that appears transitory, rather than permanent, in nature.

Table 6 reports coefficients of regression models identical to the ones reported in Table 4, except the standard measure of homogeneity is replaced with this residual measure. Across specifications, the coefficient on this measure is slightly closer to zero than the equivalent coefficient in Table 4. This pattern is consistent with the notion that endogenous sorting of more generous individuals into more diverse areas biases coefficients away from zero. The magnitude of the bias, at least as revealed by this procedure, is relatively small. Consider the coefficient estimates in the final columns of both tables. While the original parameter estimate suggests that a standard deviation increase in homogeneity leads to a 0.9 percentage point decrease in support for Gore, this corrected version implies an effect of 0.7 percentage points. The variation in parameter estimates is well within one standard error.

The estimates presented in preceding tables can be used to infer patterns in individual behavior only under a set of assumptions: that individual voters' propensity to support Democratic candidates is a linear function of group shares, and that the slope coefficients describing this relationship obey a number of parameter restrictions. As a check on these assumptions, Table 7 presents the results of linear probability model regression specifications that utilize individual-level data, rather than geographic aggregates. ${ }^{21}$ The primary advantage of

21 Probit specifications produce qualitatively similar results. The linear models are presented for ease of interpretation and comparability with the aggregated results above. 
individual data is that they permit an assessment of whether aggregation bias severely contaminates the estimates derived in county-level regressions. The primary drawback of these analyses is small sample size: only two voter polls conducted in 2000 recorded information on the candidate supported by the respondent in the presidential election, respondent's income, and respondent's county of residence. The estimation sample used in Table 7 pools these two polls.

The first specification utilizes only three control variables: indicators for whether respondents fell into two of three basic income categories available in the poll data (between $\$ 30,000$ and $\$ 75,000$, and over $\$ 75,000)$, and a county-level control for the share of residents in the respondent's county who belonged to the same income group..$^{22}$ Results indicate a monotonic negative relationship between income category and the propensity to vote for $\mathrm{Al} \mathrm{Gore.}$

Controlling for income category, individuals who reside in counties where a higher proportion of households fall into their income category are significantly less likely to support the Democratic candidate. Adopting a behavioral interpretation, the results suggest that a one-percentage-point increase in group share produces an 0.47 percentage point reduction in the probability of voting for Gore. A one-standard deviation increase in this measure predicts a 4.7 percentage point drop in this probability. Thus while from a behavioral perspective this coefficient appears smaller than the analogous estimates derived from county-level specifications, the effect size as traditionally measured is considerably larger here. ${ }^{23}$

The second specification in Table 7 controls for the share of voters in higher and lower income categories, relative to the respondent. Holding voters' own income category constant,

22 The original polling data report income in five categories; they have been collapsed here in a manner that most closely matches the categorizations used in the county-level regressions. Standard errors in these specifications have been adjusted for clustering at the county/income category level. The 1,278 individuals included in the sample belong to 901 different clusters.

23 From a behavioral perspective, the inequality of results could also be explained by the use of different income cagetory definitions in the individual-level and geographically aggregated specifications. 
support for Al Gore increases significantly with the share of households in higher income categories. Using a behavioral interpretation, increasing the share of the population with higher incomes by 1 percentage point increases the probability of voting for Gore by 0.66 percentage points. There is also a positive coefficient on the share of households in lower income categories, consistent with altruistic motives for some voters, though that estimate is not significantly different from zero. Comparing the coefficients on the lower and higher income share variables shows the impact for moderate-income voters of switching neighbors directly from the lower to higher income category. As expected, the greater magnitude of the highincome-share coefficient implies that support for redistribution increases in that scenario. Note that with these two controls in place, the coefficients on income category indicators become indistinguishable from zero.

The last two specifications in Table 7 introduce growing numbers of additional covariates into the specification. These additional covariates are sufficient to eliminate the statistical significance of the income share variables, though point estimates continue to suggest that voters become more favorably disposed toward redistribution as their neighbors become richer. The individual-level covariates produce largely intuitive effects: support for the Democratic party is strongest among the less educated, racial minorities, the childless, women, and the divorced or never-married. Upon introducing the community-level characteristics employed in Table 4, the coefficient on the share-of-population-with-lower income variable becomes negative and insignificant, and the coefficient on the share-of-population-with-higher income is reduced to half its initial magnitude, with a $t$-statistic of roughly 1.5. In the end, the individual-level data produces results fully consistent with the theoretical model, and effect sizes that are substantial 
from an absolute perspective. The ultimate lack of statistical significance, however, does limit the corroborative value of these results.

The presidential election of 2000 was in many respects highly unusual. Can these results be generalized to a more "typical" election? Table 8 reports the results of regression specifications identical to those in Table 4, using county-level voting data from the 1980 election matched to Census socioeconomic and demographic information from that year. Whereas the 2000 election was unbearably close, the 1980 election was something of a landslide, with Ronald Reagan winning election with a margin of nearly ten percentage points. Democratic candidate Jimmy Carter won electoral votes from only five states, three of which lie below the MasonDixon line. ${ }^{24}$ Although the elections of 1980 and 2000 were won by candidates from the same party, in other respects they present mark contrasts with one another.

The results reveal important differences in patterns of support for Carter and Gore in elections separated by twenty years. Carter enjoyed comparatively weaker support in counties with sizable nonwhite populations and stronger support in counties with a large share of manufacturing employment. Racially homogeneous counties tended to side with Gore but against Carter. Sixteen years before a Democratic president declared an end to the "era of big government," government employees showed much stronger support for Carter, relative to the support shown to Gore two decades later.

In contrast to these striking differences, the effect of income homogeneity on support for Carter is significant and negative in all specifications except the simple bivariate model. While coefficient magnitudes are generally reduced relative to their counterparts in Table 4, it should be noted that the standard deviation of the income homogeneity index is significantly larger in

24 Carter also won electoral votes from the District of Columbia. 
the 1980 data. A good portion of this difference can be attributed to the use of finer income categorizations in the 1980 Census, rather than any true difference in the variance of income distributions across counties. The impact of a one-standard-deviation increase in income homogeneity on support for Carter, based on the fixed effects specification in the table's last column, is a decline of 1 percentage point - nearly identical to the effect size indicated by the equivalent specification in Table $4 .^{25}$

\section{Conclusions}

Thomas Frank's popular book What's the Matter With Kansas posits that the Republican party has effectively convinced working-class Americans to vote against their economic selfinterest. Up to this point, the best explanation available in the economic literature for the same phenomenon rests on an untenable hypothesis - that Kansans have higher expectations for upward income mobility than other voters, even though the income distribution in that state is decidedly compact. This paper offers a new explanation for voting patterns in late-twentieth century America, inspired by an established yet growing body of research identifying relative consumption as an important determinant of individual well-being. The model developed in this paper, empirically supported by county and individual-level empirical evidence on voting patterns in 1980 and 2000, suggests that low- and moderate-income voters are less supportive of redistribution when they evaluate their well-being by comparing themselves to other low-income households. High-income voters also appear to support redistribution more fervently when residing in heterogeneous communities, possibly because exposure to the poor breeds either true

25 In an unreported specification matching that used in the third column of Table 5, the 1980 data reveal a continued tendency for moderate-income voters to be more supportive of Democratic candidates as the population shifts from lower- to higher-income voters. 
altruism or a self-interested desire to appease the masses.

Can this relativistic view of economic self-interest truly explain what a social scientist might term the "Kansas effect?" Table 9 provides some insight as to the relative explanatory power of income homogeneity and voters' position in the income distribution. The table begins by listing actual Democrat vote shares for each of the 50 states and the District of Columbia. The second column shows a predicted value for each state based on a county-level regression controlling for exactly five variables: the low- and middle-income shares as defined in Table 4, the low-income group share squared, an interaction between the low- and middle-income shares, and an interaction between the middle- and high-income shares. ${ }^{26}$ The third column indicates whether this prediction correctly forecasts the winner of the state's electoral votes in 2000 . The third column shows the proportion of the state's deviation from the national average that can be explained by this simple model. This parsimonious model generates correct predictions in 34 of 51 states, including Kansas.

. For comparative purposes, the final column reports the predicted values from a more complete regression that adds the additional control variables employed in Table 4. The predicted values listed in boldface type show situations where the complete model corrects an erroneous forecast made by the simple model. There are seven such instances, of a possible seventeen, almost entirely in Southern states. Of the remaining ten states, nine supported Gore in spite of predictions to the contrary: these are states with a progressive reputation including Minnesota, Oregon, and Vermont. The model thus suggests that a book title with greater support from a political economy model would be "What's the matter with Maine?"

Ex-post political prognostication aside, these results also provide further evidence to

26 This regression is weighted by the number of votes cast in the election. 
support prior theoretical work on the optimal structure of taxation, expenditure, and redistributive policy when relative consumption, or an individual's position in the consumption distribution, determines an individual's subjective well-being. Further research on the nature of such relative preferences may play an important role both in the design of superior policies, and the production of more preferable policy platforms. For example, a finding that absolute consumption is a primary determinant of utility up to some subsistence level would suggest a rational ceiling for transfer levels. The more exact determination of individuals' reference groups, and the discovery of means of changing those reference groups, could yield important insights regarding methods of improving individuals' perceptions of their own well-being with minimal cost outlays. Of course, paternalistic arguments in favor of traditional policies can always be made in opposition to considerations of relativity in utility functions. History suggests, however, that the candidate who can offer the most appealing menu of policies to the greatest share of voters will have a natural advantage in getting those policies enacted. 


\section{References}

Alesina, A. and E. La Ferrara "Preferences for Redistribution in the Land of Opportunities." NBER Working Paper \#8267.

Alesina, A. and D. Rodrik (1994) "Distributive Politics and Economic Growth." Quarterly Journal of Economics v.109 pp.465-490.

Benabou, R. and E.A. Ok (2001a) "Social Mobility and the Demand for Redistribution: The POUM Hypothesis." Quarterly Journal of Economics v.116 pp.447-487.

Benabou, R. and E.A. Ok (2001b) "Mobility and Progressivity: Ranking Income Processes According to Equality of Opportunity." NBER Working Paper \#8431.

Benabou, R. and J. Tirole (2005) "Belief in a Just World and Redistributive Politics." NBER Working Paper \#11208.

Boskin, M. and E. Sheshinski (1978) "Optimal Redistributive Taxation When Individual Welfare Depends on Relative Income." Quartery Journal of Economics v.92 pp.589-601.

Easterlin,R.A. (2001) “Income and Happiness: Towards a Unified Theory.” Economic Journal v.111 pp.465-84.

Fair, R.C. (2002) Predicting Presidential Elections and Other Things. Stanford University Press.

Ferrer-i-Carbonell, A. (2004) "Income and Well-being: An Empirical Analysis of the Comparison Income Effect." Forthcoming, Journal of Public Economics.

Frank, R.H. (1985) Choosing the Right Pond: Human Behavior and the Quest for Status. Oxford: Oxford University Press.

Frank, T. (2004) What's the Matter with Kansas? How Conservatives Won the Hearth of America. New York: Metropolitan Books.

Frey, B.S. and A. Stutzer (2002) "What Can Economists Learn f rom Happiness Research?" Journal of Economic Literature v.40 pp.402-35.

Glaeser, E.L. (2005) “Inequality” NBER Working Paper \#11511.

Hungerman, D. (2005) "Are Church and State Substitutes? Evidence from the 1996 Welfare Reform.” Forthcoming, Journal of Public Economics. 
Jargowsky, P. (1995) "Take the Money and Run: Economic Segregation in U.S. Metropolitan Areas"

Jackson, K.T. (1985) Crabgrass Frontier: The Suburbanization of the United States. Oxford: Oxford University Press.

Layard, R. (1980) "Human Satisfactions and Public Policy" Economic Journal v.90 pp.737-50.

Lee, D.S. (2001) “The Electoral Advantage to Incumbency and Voters' Valuation of Politicians' Experience: A Regression Discontinuity Analysis of Elections to the U.S. House." NBER Working Paper \#8441.

Ljungqvist, L. and H. Uhlig (2000) "Tax Policy and Aggregate Demand Management under Catching Up with the Joneses." American Economic Review v.90 pp.356-66.

Luttmer, E.F.P. (2001) "Group Loyalty and the Taste for Redistribution." Journal of Political Economy v.109 pp.500-528.

Luttmer, E.F.P. (2005) "Neighbors as Negatives: Relative Earnings and Well-Being." Quarterly Journal of Economics v.120 pp.963-1002.

McBride, M.T. (2001) "Relative-Income Effects on Subjective Well-Being in the Cross-section." Journal of Economic Behavior and Organization v.45 pp.251-278.

Meltzer, A. and S. Richard (1981) "A Rational Theory of the Size of Government." Journal of Political Economy v.89 pp.914-927.

Ng, Y. (1987) "Relative-Income Effects and the Appropriate Level of Public Expenditure." Oxford Economic Papers v.39 pp.293-300.

Persson, T. and G. Tabellini (1994) "Is Inequality Harmful for Growth?" American Economic Review v.84 pp.600-621.

Piketty, T. and E. Saez (2003) “Income Inequality in the United States, 1913-1998." Quarterly Journal of Economics v.118 pp.1-39.

Rhode, P. and K. Strumpf (2003) “Assessing the Importance of Tiebout Sorting: Local Heterogeneity from 1850 to 1990." American Economic Review v.93 pp.1648-1677.

Shapiro, M. and J. Slemrod (2003) “Consumer Responses to Tax Rebates." American Economic Review v.92 pp.381-96.

Stutzer, A. (2004) "The Role of Income Aspirations in Individual Happiness." Journal of Economic Behavior and Organization v.54 pp.89-110. 
Tocqueville, A. (1835) Democracy in America. Translated and edited by H.C. Mansfield and D. Winthrop, 2000. Chicago: University of Chicago Press.

Tomes, N. (1986) "Income Distribution, Happiness and Satisfaction: A Direct Test of the Interdependent Preferences Model." Journal of Economic Psychology v.7 pp.425-446.

Vigdor, J.L. (2002) “Interpreting Ethnic Fragmentation Effects."Economics Letters, v.75 pp.271276.

Vigdor, J.L. (2004) "Community Composition and Collective Action: Analyzing Initial Mail Response to the 2000 Census." Review of Economics and Statistics v.86 pp. 303-312.

Yelowitz, A. (1995) "The Medicaid Notch, Labor Supply and Welfare Participation: Evidence From Eligibility Expansions.” Quarterly Journal of Economics v.110 pp.909-939. 
Table 1: Examples derived from the theoretical model

\begin{tabular}{cccc}
\hline Population & $\gamma$ & $\begin{array}{c}\text { Median voter's } \\
\text { reference person }\end{array}$ & $\begin{array}{c}\text { Median voter's optimal } \\
\beta\end{array}$ \\
\hline $0,0,1$ & --- & --- & $1 / 2$ \\
$0,1,1$ & --- & --- & 1 \\
$0,1,2$ & --- & --- & $5 / 7$ \\
$0,0,1$ & $0 \leq \gamma<1$ & 0 & $1 / 2$ \\
$0,0,1$ & 1 & 0 & $0 \leq \beta \leq 1$ \\
$0,0,1$ & 0 & 1 & $1 / 2$ \\
$0,0,1$ & $1 / 2$ & 1 & $1 / 5$ \\
$0,0,1$ & 1 & 1 & 0 \\
$0,1,2$ & $1 / 2$ & 2 & $5 / 16$ \\
$0,1,2$ & $1 / 2$ & 0 & 1 \\
\hline \hline
\end{tabular}


Table 2: County-level summary statistics, 2000 dataset $(N=3,113)$

\begin{tabular}{|c|c|c|c|c|}
\hline Variable & Mean & Std. Dev. & Minimum & Maximum \\
\hline Gore's share of two-party vote & 0.502 & 0.132 & 0.069 & 0.905 \\
\hline Income homogeneity index & 0.079 & 0.007 & 0.069 & 0.235 \\
\hline Percent Black & 0.117 & 0.130 & 0 & 0.861 \\
\hline Percent Asian & 0.033 & 0.047 & 0 & 0.462 \\
\hline Percent American Indian & 0.008 & 0.027 & 0 & 0.937 \\
\hline Percent Pacific Islander & 0.001 & 0.006 & 0 & 0.109 \\
\hline Percent Other Race & 0.046 & 0.060 & 0 & 0.398 \\
\hline Percent Multiracial & 0.024 & 0.018 & 0 & 0.293 \\
\hline Percent Hispanic & 0.105 & 0.134 & 0 & 0.981 \\
\hline Racial homogeneity index & 0.663 & 0.188 & 0.266 & 1 \\
\hline $\begin{array}{l}\text { Percent of housing built in past } 10 \\
\text { years }\end{array}$ & 0.326 & 0.149 & 0.049 & 0.870 \\
\hline Owner-occupancy rate & 0.673 & 0.108 & 0.195 & 0.895 \\
\hline Percent single-family detached houses & 0.613 & 0.142 & 0.003 & 0.942 \\
\hline $\begin{array}{l}\text { Percent of households residing in } \\
\text { same house five years ago }\end{array}$ & 0.545 & 0.072 & 0.154 & 0.806 \\
\hline Percent employed in manufacturing & 0.142 & 0.070 & 0 & 0.486 \\
\hline Percent employed by government & 0.149 & 0.050 & 0.061 & 0.691 \\
\hline Percent active-duty military & 0.005 & 0.016 & 0 & 0.617 \\
\hline $\begin{array}{l}\text { Percent of households with incomes } \\
\text { below } \$ 24,999\end{array}$ & 0.359 & 0.097 & 0.061 & 0.692 \\
\hline $\begin{array}{l}\text { Percent of households with incomes } \\
\text { between } \$ 25,000 \text { and } \$ 74,999\end{array}$ & 0.501 & 0.054 & 0.274 & 0.648 \\
\hline
\end{tabular}

Note: Unit of observation is the county or county-equivalent; observations are weighted by votes cast in the 2000 Presidential election. 
Table 3: Summary statistics for individual-level regression covariates $(\mathrm{N}=1,287)$

\begin{tabular}{lcccc}
\hline Variable & Mean & Std. Dev. & Minimum & Maximum \\
\hline Income between \$30k and \$75k & 0.518 & --- & 0 & 1 \\
Income over \$75k & 0.250 & --- & 0 & 1 \\
Own income group's share in & 0.378 & 0.103 & 0.050 & 0.737 \\
county of residence & & & & \\
Share in lower income categories in & 0.254 & 0.231 & 0 & 0.823 \\
county of residence & & & & \\
Share in higher income categories & 0.368 & 0.271 & 0 & 0.950 \\
in county of residence & & & & \\
Black & 0.087 & --- & 0 & 1 \\
Asian & 0.012 & --- & 0 & 1 \\
Other race & 0.036 & --- & 0 & 1 \\
High school graduate & 0.056 & --- & 0 & 1 \\
Some college & 0.246 & --- & 0 & 1 \\
College graduate & 0.255 & --- & 0 & 1 \\
Postgraduate education & 0.155 & --- & 0 & 1 \\
Widowed & 0.096 & --- & 0 & 1 \\
Divorced & 0.132 & --- & 0 & 1 \\
Separated & 0.015 & --- & 0 & 1 \\
Never married & 0.160 & --- & 0 & 1 \\
Children present in household & 0.383 & --- & 0 & 1 \\
Female & 0.596 & --- & 0 & 1 \\
Voted for Gore in 2000 election & 0.485 & --- & 0 & 1 \\
\hline No: Unit of & & & 0 & 1 \\
\hline
\end{tabular}

Note: Unit of observation is the individual voter. Data sources are CBS/New York Times polls taken in November and December 2000, ICPSR studies \#3231 and 3238. 
Table 4: Basic regression results, 2000 data

\begin{tabular}{|c|c|c|c|c|c|}
\hline \multirow{2}{*}{$\begin{array}{l}\text { Independent variable } \\
\text { Income homogeneity index }\end{array}$} & \multicolumn{5}{|c|}{ Dependent variable: Gore's share of the two-party vote } \\
\hline & $\begin{array}{c}-1.88 \\
(0.327)\end{array}$ & $\begin{array}{l}-7.58 \\
(0.319)\end{array}$ & $\begin{array}{l}-2.33 \\
(0.328)\end{array}$ & $\begin{array}{l}-1.109 \\
(0.270)\end{array}$ & $\begin{array}{l}-1.256 \\
(0.258)\end{array}$ \\
\hline Percent Black & - & - & $\begin{array}{c}0.572 \\
(0.031)\end{array}$ & $\begin{array}{c}0.556 \\
(0.031)\end{array}$ & $\begin{array}{c}0.607 \\
(0.028)\end{array}$ \\
\hline Percent Asian & - & - & $\begin{array}{c}0.685 \\
(0.070)\end{array}$ & $\begin{array}{c}0.526 \\
(0.066)\end{array}$ & $\begin{array}{r}0.726 \\
(0.064)\end{array}$ \\
\hline Percent American Indian & - & - & $\begin{array}{c}0.377 \\
(0.059)\end{array}$ & $\begin{array}{c}0.328 \\
(0.059)\end{array}$ & $\begin{array}{c}0.367 \\
(0.053)\end{array}$ \\
\hline Percent Pacific Islander & - & - & $\begin{array}{l}-6.58 \\
(0.523)\end{array}$ & $\begin{array}{l}-6.26 \\
(0.517)\end{array}$ & $\begin{array}{c}7.99 \\
(1.27)\end{array}$ \\
\hline Percent Other Race & - & - & $\begin{array}{c}0.115 \\
(0.069)\end{array}$ & $\begin{array}{c}0.084 \\
(0.069)\end{array}$ & $\begin{array}{c}0.085 \\
(0.068)\end{array}$ \\
\hline Percent Multiracial & - & - & $\begin{array}{l}3.327 \\
(0.216)\end{array}$ & $\begin{array}{l}3.418 \\
(0.216)\end{array}$ & $\begin{array}{c}2.23 \\
(0.236)\end{array}$ \\
\hline Percent Hispanic & - & - & $\begin{array}{c}0.071 \\
(0.027)\end{array}$ & $\begin{array}{c}0.060 \\
(0.027)\end{array}$ & $\begin{array}{c}0.139 \\
(0.025)\end{array}$ \\
\hline Racial homogeneity index & - & - & $\begin{array}{c}0.383 \\
(0.030)\end{array}$ & $\begin{array}{c}0.357 \\
(0.030)\end{array}$ & $\begin{array}{c}0.257 \\
(0.028)\end{array}$ \\
\hline Percent urban & - & - & $\begin{array}{c}0.057 \\
(0.011)\end{array}$ & $\begin{array}{c}0.076 \\
(0.010)\end{array}$ & $\begin{array}{c}0.075 \\
(0.009)\end{array}$ \\
\hline $\begin{array}{l}\text { Percent of housing units built in last } \\
\text { ten years }\end{array}$ & - & - & $\begin{array}{l}-0.227 \\
(0.019)\end{array}$ & $\begin{array}{l}-0.204 \\
(0.018)\end{array}$ & $\begin{array}{l}-0.069 \\
(0.020)\end{array}$ \\
\hline Home ownership rate & - & - & $\begin{array}{c}0.070 \\
(0.036)\end{array}$ & $\begin{array}{l}-0.021 \\
(0.033)\end{array}$ & $\begin{array}{l}-0.029 \\
(0.033)\end{array}$ \\
\hline $\begin{array}{l}\text { Percent single-family detached } \\
\text { housing }\end{array}$ & - & - & $\begin{array}{l}-0.289 \\
(0.017)\end{array}$ & $\begin{array}{l}-0.286 \\
(0.017)\end{array}$ & $\begin{array}{l}-0.166 \\
(0.017)\end{array}$ \\
\hline $\begin{array}{l}\text { Percent living in same house five } \\
\text { years ago }\end{array}$ & - & - & $\begin{array}{c}0.219 \\
(0.041)\end{array}$ & $\begin{array}{c}0.318 \\
(0.039)\end{array}$ & $\begin{array}{c}0.351 \\
(0.043)\end{array}$ \\
\hline Percent employed in manufacturing & - & - & $\begin{array}{l}-0.037 \\
(0.029)\end{array}$ & $\begin{array}{c}0.017 \\
(0.028)\end{array}$ & $\begin{array}{l}-0.065 \\
(0.027)\end{array}$ \\
\hline Percent employed by government & - & - & $\begin{array}{c}0.028 \\
(0.041)\end{array}$ & $\begin{array}{c}0.102 \\
(0.039)\end{array}$ & $\begin{array}{c}0.107 \\
(0.036)\end{array}$ \\
\hline Percent active-duty military & - & - & $\begin{array}{l}-0.436 \\
(0.096)\end{array}$ & $\begin{array}{l}-0.630 \\
(0.094)\end{array}$ & $\begin{array}{l}-0.589 \\
(0.079)\end{array}$ \\
\hline Percent with incomes below 24,999 & - & - & - & $\begin{array}{l}-0.126 \\
(0.024)\end{array}$ & $\begin{array}{c}0.071 \\
(0.027)\end{array}$ \\
\hline $\begin{array}{l}\text { Percent with incomes } \$ 25,000 \text { - } \\
\$ 74,999\end{array}$ & - & - & - & $\begin{array}{l}-0.259 \\
(0.043)\end{array}$ & $\begin{array}{l}-0.264 \\
(0.042)\end{array}$ \\
\hline Detailed income categorizations? & No & Yes & Yes & No & No \\
\hline State fixed effects? & No & No & No & No & Yes \\
\hline $\mathrm{N}$ & 3,113 & 3,113 & 3,113 & 3,113 & 3,113 \\
\hline $\mathrm{R}^{2}$ & 0.011 & 0.402 & 0.682 & 0.672 & 0.786 \\
\hline
\end{tabular}

Note: Standard errors in parentheses. Unit of observation is the county or county equivalent; observations are weighted by number of votes cast in the 2000 presidential election. 
Table 5: Testing for heterogeneity in the effect of homogeneity

Dependent variable:

Independent variable Gore's share of the two-party vote

Income homogeneity index

0.084

(0.423)

Income homogeneity* percent urban

$-2.11$

$(0.527)$

"Low" income group share

0.059

$-0.083$

2.125

(0.027)

$(0.161)$

(0.260)

"Middle" income group share

$-0.247$

$-2.437$

0.075

(0.042)

(0.507)

(0.081)

"Low" income group share squared

$-0.662$

$-1.766$

$(0.195)$

$(0.227)$

"Middle" income group share squared

1.407

(0.464)

"High" income group share squared

$-1.104$

(0.170)

"Middle" income group share * "Low"

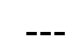

$-2.512$

income group share

(0.552)

"Middle" income group share * "High"

--- - - - - -

$-0.303$

income group share

Table 2, last column controls (incl. State FE)

Yes

Yes

Yes

$\mathrm{N}$

3,113

3,113

3,113

$\mathrm{R}^{2}$

0.787

0.789

0.789

Note: Standard errors in parentheses. Unit of observation is the county or county equivalent; observations are weighted by number of votes cast in the 2000 presidential election. 
Table 6: Addressing the potential for endogenous sorting

\begin{tabular}{|c|c|c|c|c|c|}
\hline \multirow{2}{*}{$\begin{array}{l}\text { Independent variable } \\
\text { Income homogeneity index, } \\
\text { orthogonalized to } 1980 \\
\text { income homogeneity index }\end{array}$} & \multicolumn{5}{|c|}{ Dependent variable: Gore's share of the two-party vote } \\
\hline & $\begin{array}{c}-1.41 \\
(0.351)\end{array}$ & $\begin{array}{c}-7.42 \\
(0.344)\end{array}$ & $\begin{array}{c}-2.24 \\
(0.324)\end{array}$ & $\begin{array}{l}-1.017 \\
(0.269)\end{array}$ & $\begin{array}{l}-1.112 \\
(0.251)\end{array}$ \\
\hline Detailed income categories? & No & Yes & Yes & No & No \\
\hline $\begin{array}{l}\text { Additional community } \\
\text { covariates? }\end{array}$ & No & No & Yes & Yes & Yes \\
\hline Basic income categories? & No & No & No & Yes & Yes \\
\hline State fixed effects? & No & No & No & No & Yes \\
\hline $\mathrm{N}$ & 3,103 & 3,103 & 3,103 & 3,103 & 3,103 \\
\hline $\mathrm{R}^{2}$ & 0.005 & 0.388 & 0.682 & 0.672 & 0.786 \\
\hline
\end{tabular}

Note: Standard errors in parentheses. Unit of observation is the county or county equivalent; observations are weighted by number of votes cast in the 2000 presidential election. 
Table 7: Estimating the model with individual-level data

\begin{tabular}{|c|c|c|c|c|}
\hline \multirow{2}{*}{$\begin{array}{l}\text { Independent Variable } \\
\text { Income between } \$ 30,000 \text { and } 75,000\end{array}$} & \multicolumn{4}{|c|}{ Dependent variable: Individual voted for Gore in 2000 election } \\
\hline & $\begin{array}{l}-0.157 \\
(0.034)\end{array}$ & $\begin{array}{l}-0.031 \\
(0.074)\end{array}$ & $\begin{array}{c}0.023 \\
(0.072)\end{array}$ & $\begin{array}{c}0.061 \\
(0.088)\end{array}$ \\
\hline Income above $\$ 75,000$ & $\begin{array}{l}-0.310 \\
(0.046)\end{array}$ & $\begin{array}{l}-0.085 \\
(0.125)\end{array}$ & $\begin{array}{c}0.024 \\
(0.123)\end{array}$ & $\begin{array}{c}0.096 \\
(0.051)\end{array}$ \\
\hline $\begin{array}{l}\text { Own income group's share in county of } \\
\text { residence }\end{array}$ & $\begin{array}{l}-0.472 \\
(0.181)\end{array}$ & --- & --- & --- \\
\hline $\begin{array}{l}\text { Share in lower income categories in } \\
\text { county of residence }\end{array}$ & --- & $\begin{array}{c}0.320 \\
(0.197)\end{array}$ & $\begin{array}{c}0.107 \\
(0.187)\end{array}$ & $\begin{array}{l}-0.027 \\
(0.199)\end{array}$ \\
\hline $\begin{array}{l}\text { Share in higher income categories in } \\
\text { county of residence }\end{array}$ & --- & $\begin{array}{c}0.656 \\
(0.204)\end{array}$ & $\begin{array}{c}0.347 \\
(0.195)\end{array}$ & $\begin{array}{c}0.304 \\
(0.206)\end{array}$ \\
\hline High school graduate & --- & --- & $\begin{array}{l}-0.092 \\
(0.051)\end{array}$ & $\begin{array}{l}-0.092 \\
(0.051)\end{array}$ \\
\hline Some college & --- & --- & $\begin{array}{l}-0.108 \\
(0.052)\end{array}$ & $\begin{array}{l}-0.113 \\
(0.053)\end{array}$ \\
\hline College graduate & --- & --- & $\begin{array}{l}-0.074 \\
(0.057)\end{array}$ & $\begin{array}{l}-0.079 \\
(0.058)\end{array}$ \\
\hline Postgraduate education & --- & --- & $\begin{array}{l}-0.080 \\
(0.063)\end{array}$ & $\begin{array}{l}-0.094 \\
(0.064)\end{array}$ \\
\hline Black & --- & --- & $\begin{array}{c}0.477 \\
(0.042)\end{array}$ & $\begin{array}{c}0.473 \\
(0.047)\end{array}$ \\
\hline Asian & --- & --- & $\begin{array}{c}0.158 \\
(0.124)\end{array}$ & $\begin{array}{c}0.147 \\
(0.126)\end{array}$ \\
\hline Other race & --- & --- & $\begin{array}{c}0.195 \\
(0.065)\end{array}$ & $\begin{array}{c}0.188 \\
(0.065)\end{array}$ \\
\hline Widowed & --- & --- & $\begin{array}{c}0.006 \\
(0.054)\end{array}$ & $\begin{array}{l}-0.007 \\
(0.054)\end{array}$ \\
\hline Divorced & --- & --- & $\begin{array}{c}0.095 \\
(0.048)\end{array}$ & $\begin{array}{c}0.097 \\
(0.048)\end{array}$ \\
\hline Separated & --- & --- & $\begin{array}{c}0.172 \\
(0.112)\end{array}$ & $\begin{array}{c}0.150 \\
(0.112)\end{array}$ \\
\hline Never Married & --- & --- & $\begin{array}{c}0.105 \\
(0.036)\end{array}$ & $\begin{array}{c}0.150 \\
(0.112)\end{array}$ \\
\hline Children in household & --- & --- & $\begin{array}{l}-0.091 \\
(0.027)\end{array}$ & $\begin{array}{c}-0.082 \\
(0.027)\end{array}$ \\
\hline Female & --- & --- & $\begin{array}{c}0.066 \\
(0.027)\end{array}$ & $\begin{array}{c}0.065 \\
(0.027)\end{array}$ \\
\hline Community-level characteristics & No & No & No & Yes \\
\hline $\mathrm{N}$ & 1,278 & 1,278 & 1,278 & 1,278 \\
\hline $\mathrm{R}^{2}$ & 0.038 & 0.040 & 0.169 & 0.180 \\
\hline
\end{tabular}

Note: Estimates are derived from linear probability models. Standard errors in parentheses. Community-level characteristics include share of respondent's race, percent employed in manufacturing industries, percent singlefamily detached houses, percent of housing built in the past ten years, percent urban, percent owner-occupied, percent residing in the same house five years ago, percent civilian government employees, percent employed in the armed forces. 
Table 8: Basic regression results, 1980 data

\begin{tabular}{|c|c|c|c|c|c|}
\hline \multirow{2}{*}{$\frac{\text { Independent variable }}{\text { Income homogeneity index }}$} & \multicolumn{5}{|c|}{ Dependent variable: Carter's share of the two-party vote } \\
\hline & $\begin{array}{c}0.460 \\
(0.124)\end{array}$ & $\begin{array}{l}-2.00 \\
(0.169)\end{array}$ & $\begin{array}{l}-1.103 \\
(0.243)\end{array}$ & $\begin{array}{l}-0.664 \\
(0.195)\end{array}$ & $\begin{array}{l}-0.410 \\
(0.175)\end{array}$ \\
\hline Percent Black & - & - & $\begin{array}{c}0.191 \\
(0.036)\end{array}$ & $\begin{array}{c}0.108 \\
(0.034)\end{array}$ & $\begin{array}{l}-0.093 \\
(0.035)\end{array}$ \\
\hline Percent Asian & - & - & $\begin{array}{c}0.601 \\
(0.185)\end{array}$ & $\begin{array}{c}0.333 \\
(0.187)\end{array}$ & $\begin{array}{c}0.688 \\
(0.172)\end{array}$ \\
\hline Percent American Indian & - & - & $\begin{array}{l}-0.152 \\
(0.069)\end{array}$ & $\begin{array}{l}-0.212 \\
(0.070)\end{array}$ & $\begin{array}{l}-0.164 \\
(0.065)\end{array}$ \\
\hline Percent Pacific Islander & - & - & $\begin{array}{l}-0.257 \\
(0.202)\end{array}$ & $\begin{array}{l}-0.006 \\
(0.205)\end{array}$ & $\begin{array}{c}0.792 \\
(0.266)\end{array}$ \\
\hline Percent Other Race & - & - & $\begin{array}{l}0.113 \\
(1.77)\end{array}$ & $\begin{array}{l}-1.02 \\
(1.80)\end{array}$ & $\begin{array}{l}-0.106 \\
(1.70)\end{array}$ \\
\hline Percent Hispanic & - & - & $\begin{array}{l}-0.032 \\
(0.026)\end{array}$ & $\begin{array}{l}-0.092 \\
(0.025)\end{array}$ & $\begin{array}{l}-0.048 \\
(0.026)\end{array}$ \\
\hline Racial homogeneity index & - & - & $\begin{array}{l}-0.021 \\
(0.029)\end{array}$ & $\begin{array}{l}-0.059 \\
(0.028)\end{array}$ & $\begin{array}{l}-0.268 \\
(0.028)\end{array}$ \\
\hline Percent urban & - & - & $\begin{array}{c}0.014 \\
(0.006)\end{array}$ & $\begin{array}{c}0.026 \\
(0.006)\end{array}$ & $\begin{array}{c}0.026 \\
(0.005)\end{array}$ \\
\hline $\begin{array}{l}\text { Percent of housing units built in last } \\
\text { ten years }\end{array}$ & - & - & $\begin{array}{c}0.011 \\
(0.015)\end{array}$ & $\begin{array}{l}-0.031 \\
(0.014)\end{array}$ & $\begin{array}{l}-0.017 \\
(0.016)\end{array}$ \\
\hline Home ownership rate & - & - & $\begin{array}{l}-0.118 \\
(0.028)\end{array}$ & $\begin{array}{l}-0.106 \\
(0.028)\end{array}$ & $\begin{array}{l}-0.043 \\
(0.027)\end{array}$ \\
\hline $\begin{array}{l}\text { Percent single-family detached } \\
\text { housing }\end{array}$ & - & - & $\begin{array}{l}-0.060 \\
(0.016)\end{array}$ & $\begin{array}{l}-0.061 \\
(0.016)\end{array}$ & $\begin{array}{l}-0.030 \\
(0.019)\end{array}$ \\
\hline $\begin{array}{l}\text { Percent living in same house five } \\
\text { years ago }\end{array}$ & - & - & $\begin{array}{c}0.076 \\
(0.009)\end{array}$ & $\begin{array}{c}0.076 \\
(0.008)\end{array}$ & $\begin{array}{c}0.073 \\
(0.010)\end{array}$ \\
\hline Percent employed in manufacturing & - & - & $\begin{array}{c}0.155 \\
(0.024)\end{array}$ & $\begin{array}{c}0.193 \\
(0.023)\end{array}$ & $\begin{array}{c}0.111 \\
(0.023)\end{array}$ \\
\hline Percent employed by government & - & - & $\begin{array}{c}0.321 \\
(0.037)\end{array}$ & $\begin{array}{c}0.344 \\
(0.035)\end{array}$ & $\begin{array}{r}0.286 \\
(0.034)\end{array}$ \\
\hline Percent active-duty military & - & - & $\begin{array}{l}-0.008 \\
(0.045)\end{array}$ & $\begin{array}{l}-0.106 \\
(0.044)\end{array}$ & $\begin{array}{l}-0.157 \\
(0.039)\end{array}$ \\
\hline Percent with incomes below $\$ 4,999$ & - & - & - & $\begin{array}{c}0.753 \\
(0.057)\end{array}$ & $\begin{array}{c}0.752 \\
(0.060)\end{array}$ \\
\hline $\begin{array}{l}\text { Percent with incomes } \$ 5,000 \text { - } \\
39,999\end{array}$ & - & - & - & $\begin{array}{c}0.146 \\
(0.055)\end{array}$ & $\begin{array}{c}0.244 \\
(0.051)\end{array}$ \\
\hline Detailed income categorizations? & No & Yes & Yes & No & No \\
\hline State fixed effects? & No & No & No & No & Yes \\
\hline $\mathrm{N}$ & 3,104 & 3,104 & 3,102 & 3,102 & 3,102 \\
\hline $\mathrm{R}^{2}$ & 0.004 & 0.275 & 0.455 & 0.428 & 0.598 \\
\hline
\end{tabular}

Note: Standard errors in parentheses. Unit of observation is the county or county equivalent; observations are weighted by number of votes cast in the 2000 presidential election. 
Table 9: Can the "new" economic self-interest model explain support for Gore in 2000?

\begin{tabular}{lcccc}
\hline State & Actual value & $\begin{array}{c}\text { Value predicted by basic income } \\
\text { category model }\end{array}$ & Correct prediction? & Value predicted by full model \\
\hline Alabama & 42.5 & 51.5 & No & $\mathbf{4 6 . 4}$ \\
Arkansas & 47.2 & 45.7 & Yes & 40.9 \\
Arizona & 47.5 & 49.0 & Yes & 42.1 \\
California & 56.4 & 57.3 & Yes & 56.6 \\
Colorado & 45.5 & 45.8 & Yes & 44.4 \\
Connecticut & 59.3 & 59.0 & Yes & 56.4 \\
District of Columbia & 90.5 & 70.5 & Yes & 92.2 \\
Delaware & 56.9 & 49.4 & No & $\mathbf{5 0 . 8}$ \\
Florida & 49.998 & 50.1 & No & $\mathbf{4 8 . 4}$ \\
Georgia & 44.0 & 49.1 & Yes & 44.8 \\
Hawaii & 59.8 & 54.6 & Yes & 63.7 \\
Iowa & 50.2 & 41.6 & No & 43.7 \\
Idaho & 29.1 & Yes & 40.3 \\
Illinois & 52.4 & Yes & 53.7 \\
Indiana & 50.0 & Yes & 44.4 \\
Kansas & 46.2 & Yes & 44.3 \\
Kentucky & 42.0 & Yes & 43.4 \\
Louisiana & 38.9 & 42.2 & No & 52.0 \\
Massachusetts & 42.3 & 49.8 & Yes & 59.3 \\
Maryland & 46.1 & 54.4 & No & $\mathbf{5 7 . 9}$ \\
Maine & 64.7 & 59.2 & No & 43.8 \\
Michigan & 58.5 & 46.6 & Yes & 51.1
\end{tabular}


Table 9: Can the "new" economic self-interest model explain support for Gore in 2000?

\begin{tabular}{lcccc}
\hline State & Actual value & $\begin{array}{c}\text { Value predicted by basic income } \\
\text { category model }\end{array}$ & Correct prediction? & Value predicted by full model \\
\hline Minnesota & 51.3 & 44.4 & No & 47.3 \\
Missouri & 48.3 & 44.8 & Yes & 44.8 \\
Mississippi & 41.3 & 50.1 & No & $\mathbf{4 7 . 0}$ \\
Montana & 36.4 & 42.9 & Yes & 43.2 \\
North Carolina & 43.6 & 46.8 & Yes & 42.0 \\
North Dakota & 35.3 & 41.1 & Yes & 44.2 \\
Nebraska & 34.5 & 42.3 & Yes & 43.0 \\
New Hampshire & 49.3 & 45.9 & Yes & 46.3 \\
New Jersey & 58.1 & 57.1 & Yes & 59.6 \\
New Mexico & 50.0 & 49.8 & No & 46.8 \\
Nevada & 48.1 & 46.8 & Yes & 41.5 \\
New York & 62.8 & 58.5 & Yes & 64.1 \\
Ohio & 48.0 & 48.2 & Yes & 49.3 \\
Oklahoma & 38.9 & 47.0 & No & 49.2 \\
Oregon & 50.2 & No & 46.6 \\
Pennsylvania & 52.1 & 46.1 & Yes & $\mathbf{5 4 . 4}$ \\
Rhode Island & 65.6 & 55.2 & Yes & 56.7 \\
South Carolina & 41.8 & 48.4 & Yes & 45.6 \\
South Dakota & 38.4 & 40.9 & Yes & 42.5 \\
Tennessee & 48.1 & 47.8 & No & 43.5 \\
Texas & 39.0 & 51.3 & Yes & $\mathbf{4 3 . 8}$ \\
Utah & 28.3 & 42.2 & & 38.9
\end{tabular}


Table 9: Can the "new" economic self-interest model explain support for Gore in 2000?

\begin{tabular}{lcccc}
\hline State & Actual value & $\begin{array}{c}\text { Value predicted by basic income } \\
\text { category model }\end{array}$ & Correct prediction? & Value predicted by full model \\
\hline Virginia & 45.8 & 43.6 & Yes & 46.6 \\
Vermont & 55.4 & 44.6 & No & 45.1 \\
Washington & 52.8 & 47.8 & No & 48.3 \\
Wisconsin & 50.1 & 42.9 & No & 46.2 \\
West Virginia & 46.7 & 48.5 & Yes & 44.6 \\
Wyoming & 29.0 & 43.6 & Yes & 44.1 \\
\hline
\end{tabular}

Note: Predictions are based on county-level regressions employing number of votes cast in the 2000 election as weights. 


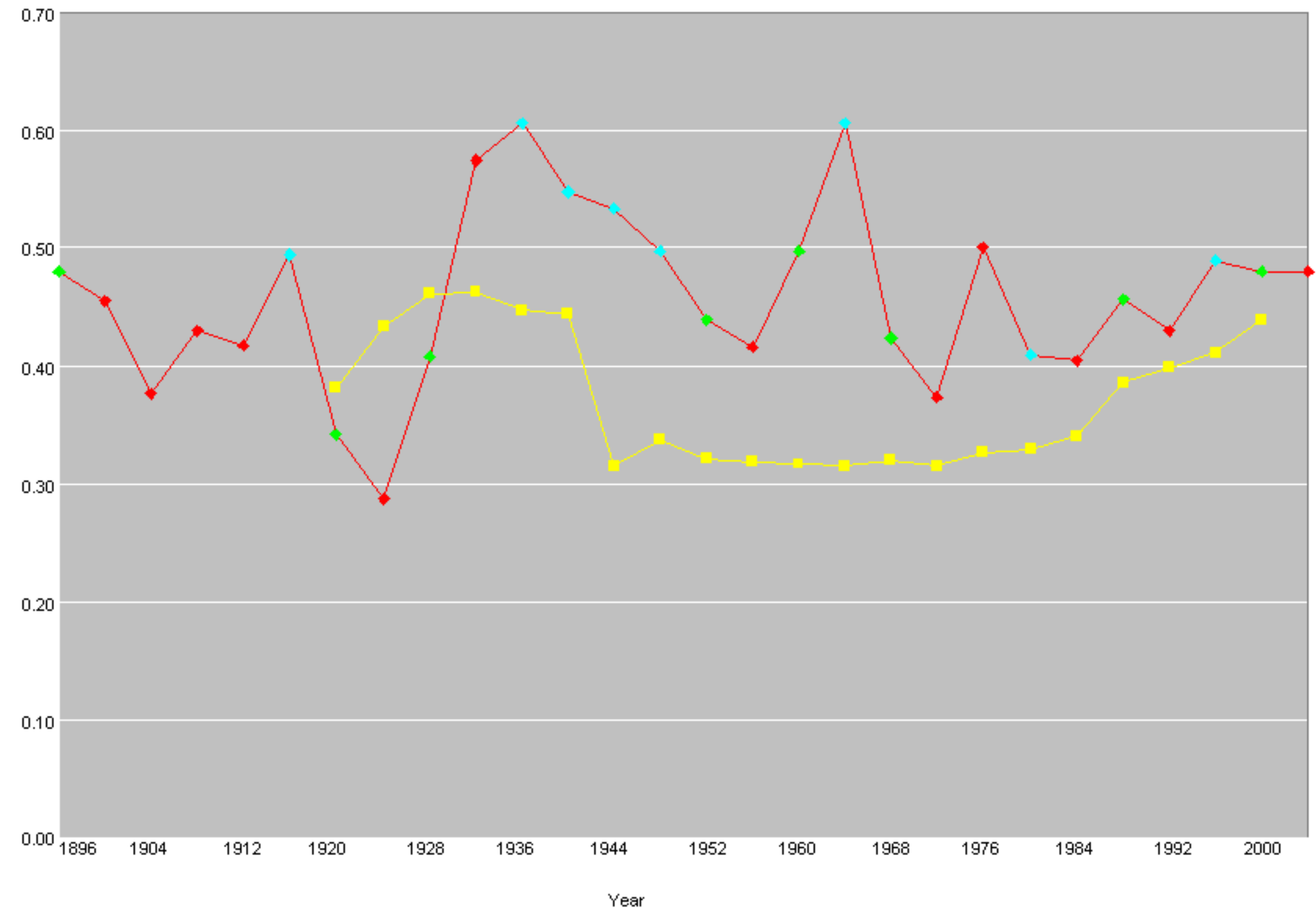

- Percent Democrat _ - Share of income to top 10 percent $\quad$ Open seat Incumbent Candidate

Figure 1: Income inequality and voting patterns, 1896-2004 


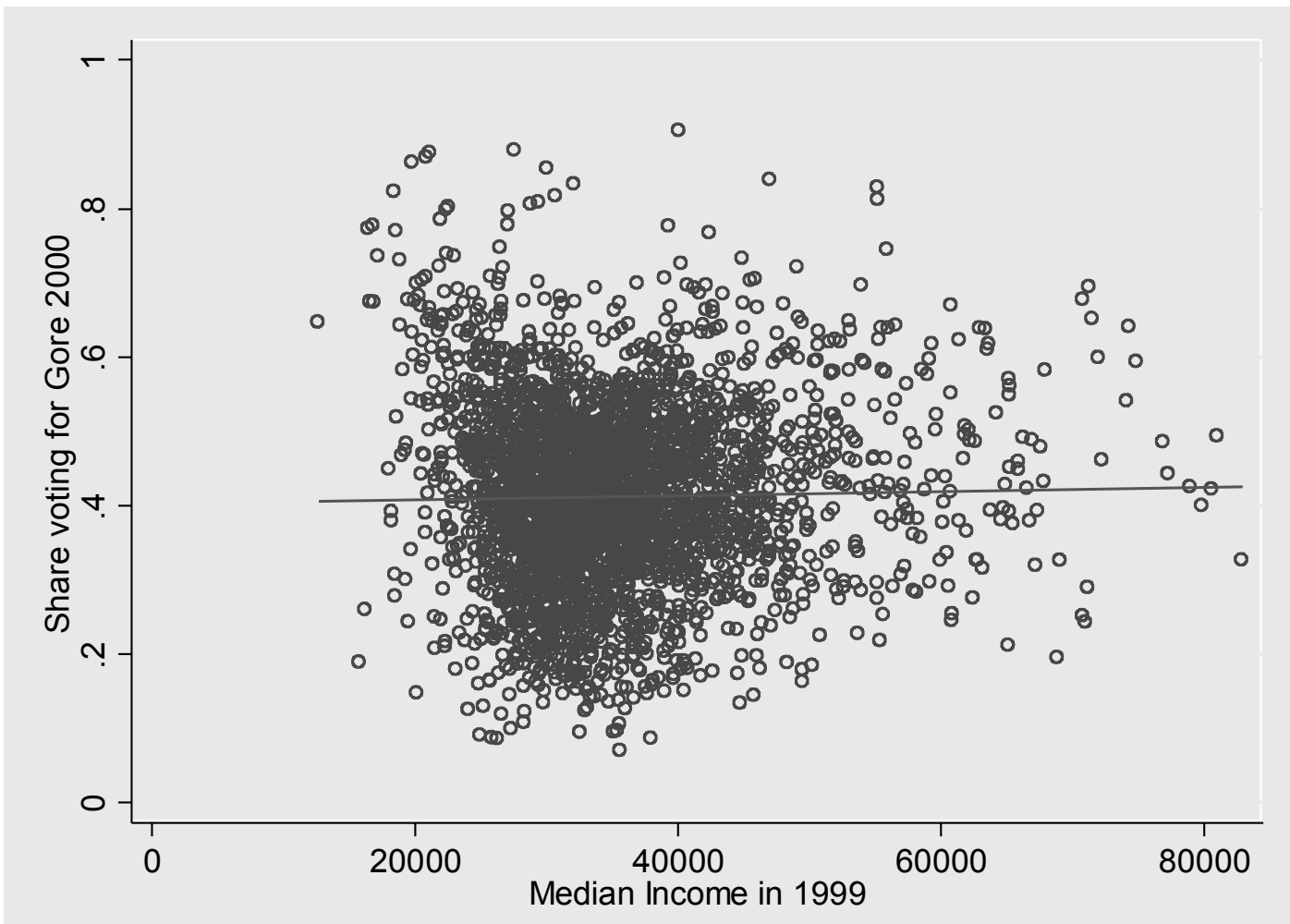

Figure 2: The bivariate relationship between county median income and Gore's share of the twoparty vote, 2000. 


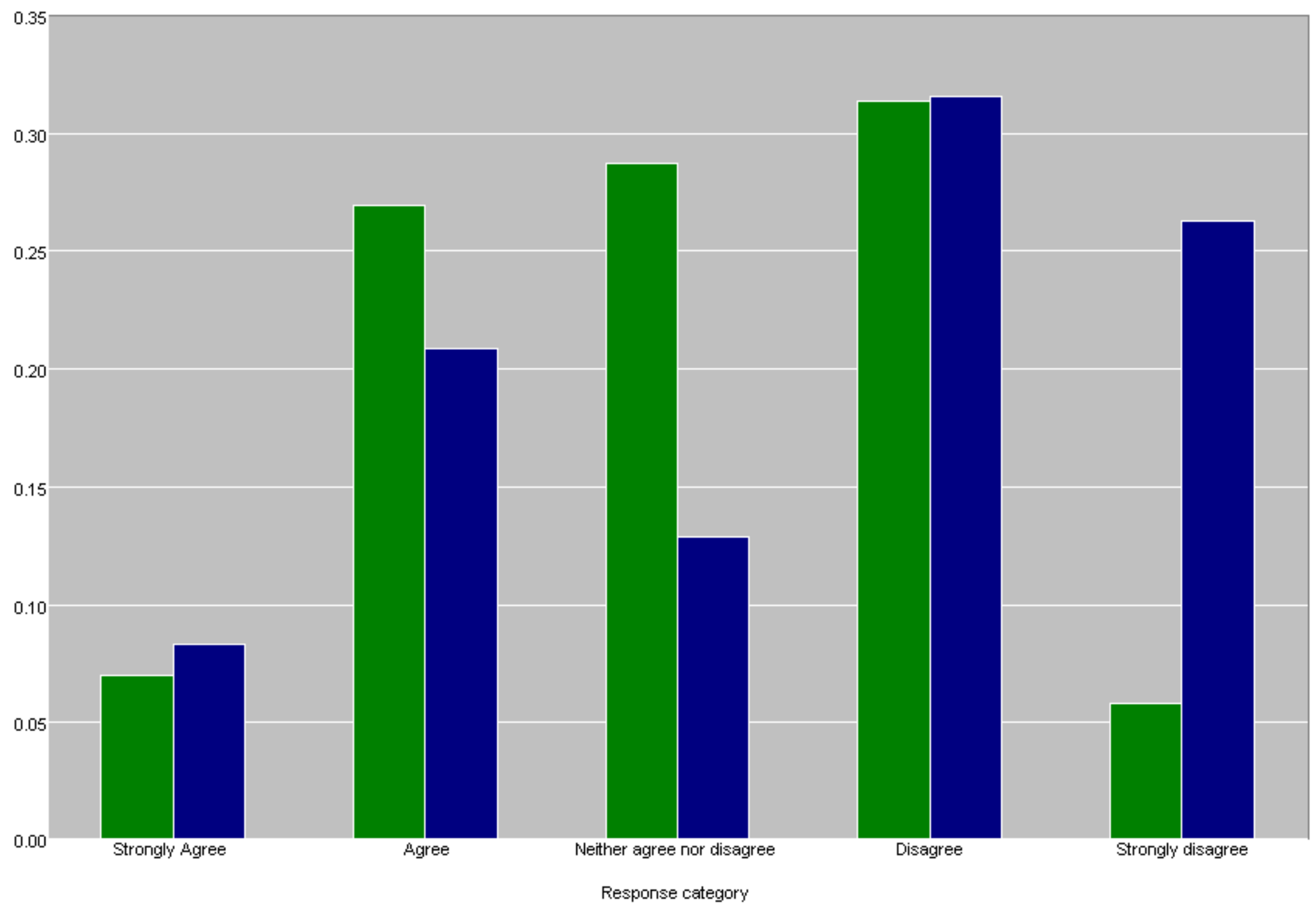

๒1983-87 - 1996

Figure 3: Responses to "Large differences in income are necessary for America's prosperity," General Social Survey 


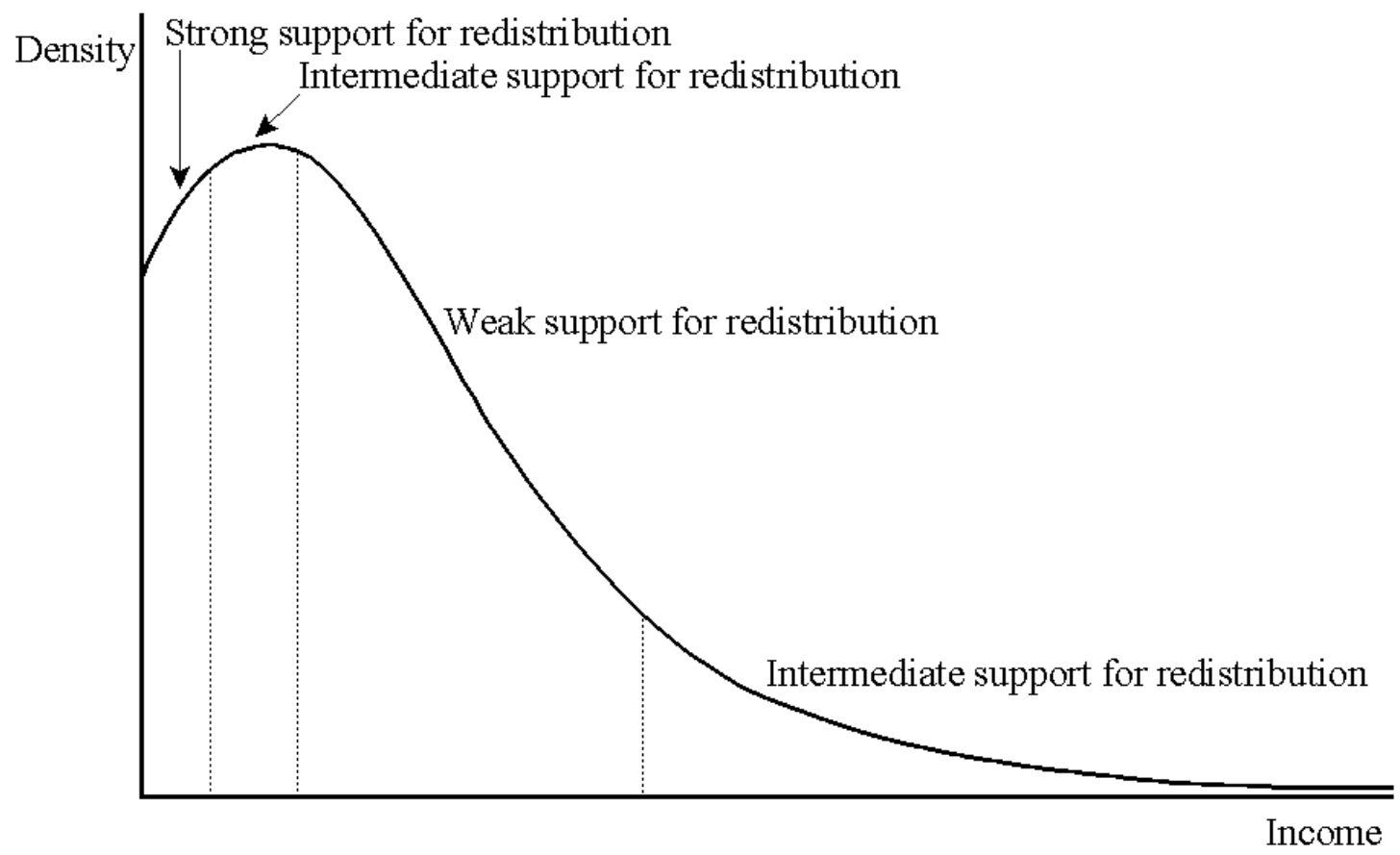

Figure 4: Support for redistribution across the income distribution when individuals define reference groups as symmetric income bands. 


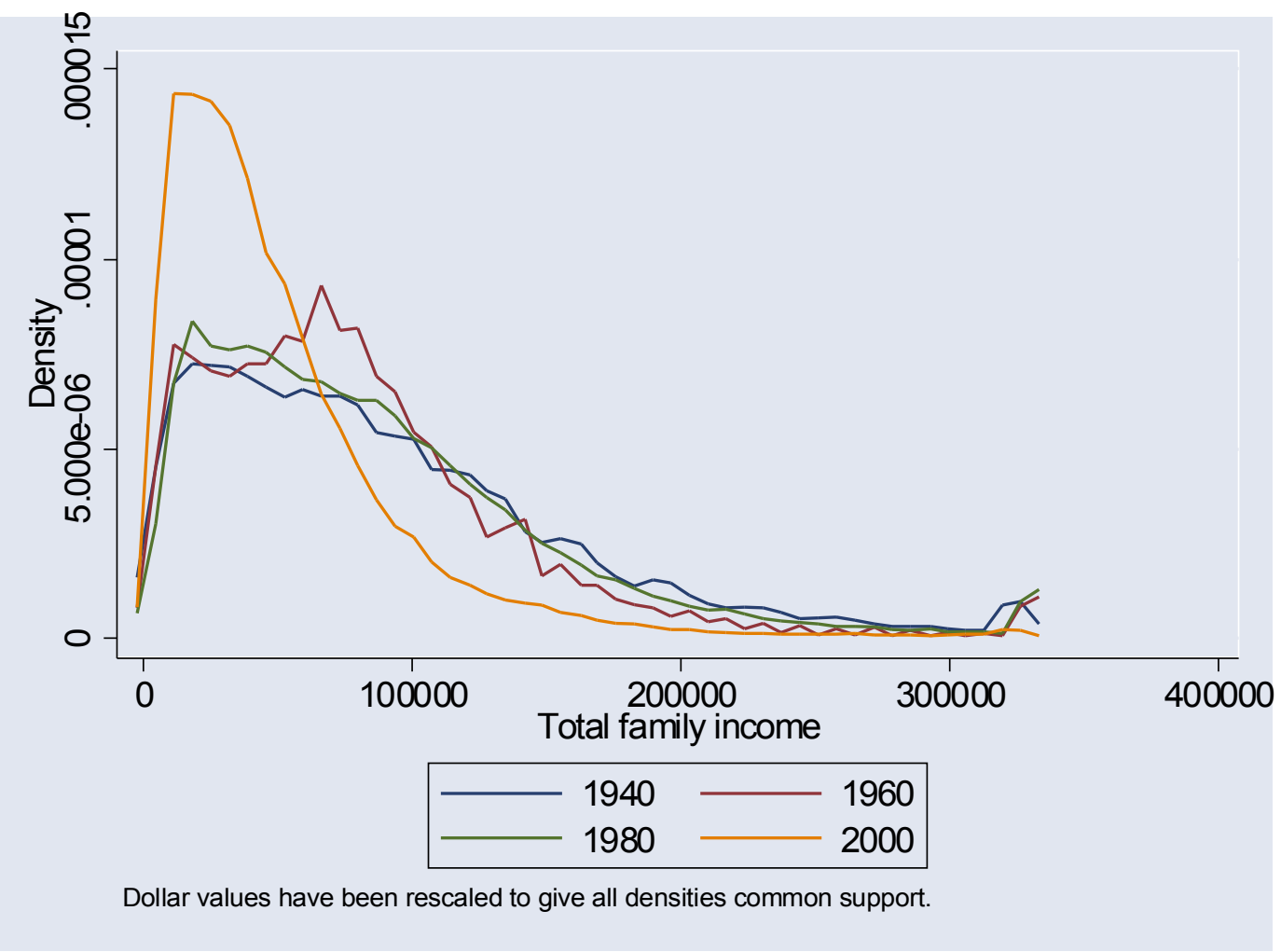

Figure 5: The income distribution in the United States, 1940-2000. Densities omit famlies with nonpositive income and the top $1 \%$ of the distribution in each year. The 1940 density uses family wage and salary income rather than total family income. Dollar values are not inflationcorrected; values have been rescaled to match the support of the 2000 income distribution. 